\title{
Re-examining the ability to explain future South African banking share returns: A data envelopment analysis approach
}

\begin{tabular}{|c|c|}
\hline \multicolumn{2}{|c|}{$\begin{array}{l}\text { Authors: } \\
\text { Chris van Heerden } 1 \text { (1) } \\
\text { Johan Coetzee }\end{array}$} \\
\hline \multicolumn{2}{|c|}{$\begin{array}{l}\text { Affiliations: } \\
{ }^{1} \text { School of Economics, Faculty } \\
\text { of Economic and } \\
\text { Management Sciences, } \\
\text { North-West University, } \\
\text { Potchefstroom, South Africa }\end{array}$} \\
\hline \multicolumn{2}{|c|}{$\begin{array}{l}{ }^{2} \text { Department of Economics } \\
\text { and Finance, Faculty of } \\
\text { Economic and Management } \\
\text { Sciences, University of the } \\
\text { Free State, Bloemfontein, } \\
\text { South Africa }\end{array}$} \\
\hline \multicolumn{2}{|c|}{$\begin{array}{l}\text { Corresponding author: } \\
\text { Johan Coetzee, } \\
\text { coetzj@ufs.ac.za }\end{array}$} \\
\hline \multicolumn{2}{|c|}{$\begin{array}{l}\text { Dates: } \\
\text { Received: } 18 \text { Oct. } 2018 \\
\text { Accepted: } 03 \text { June } 2019 \\
\text { Published: } 16 \text { Sept. } 2019\end{array}$} \\
\hline \multicolumn{2}{|c|}{$\begin{array}{l}\text { How to cite this article: } \\
\text { Van Heerden, C. \& Coetzee, J., } \\
\text { 2019, 'Re-examining the } \\
\text { ability to explain future South } \\
\text { African banking share returns: } \\
\text { A data envelopment analysis } \\
\text { approach', South African } \\
\text { Journal of Economic and } \\
\text { Management Sciences 22(1), } \\
\text { a2852. https://doi.org/ } \\
\text { 10.4102/sajems.v22i1.2852 }\end{array}$} \\
\hline \multicolumn{2}{|c|}{$\begin{array}{l}\text { Copyright: } \\
\text { (c) 2019. The Authors. } \\
\text { Licensee: AOSIS. This work } \\
\text { is licensed under the } \\
\text { Creative Commons } \\
\text { Attribution License. }\end{array}$} \\
\hline \multicolumn{2}{|l|}{ Read online: } \\
\hline 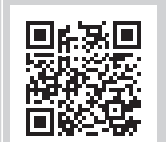 & $\begin{array}{l}\text { Scan this QR } \\
\text { code with your } \\
\text { smart phone or } \\
\text { mobile device } \\
\text { to read online. }\end{array}$ \\
\hline
\end{tabular}

Background: Using financial ratios is considered to be important when making informed judgments about investment portfolios. However, the 'ideal' set of ratios is an elusive notion on which the literature has failed to reach any consensus.

Aim: This study attempts to identify to what extent so-called 'non-financial' measures can outperform 'traditional' financial and risk-adjusted performance ratios to explain future share returns for South African banks in a momentum investment strategy.

Method: A multi-stage data envelopment analysis model was used in the study.

Results: The results suggest that non-financial measures are able to explain up to $90 \%$ of banking shares' future returns, which is a $30 \%$ to $40 \%$ improvement on that of traditional financial and risk-adjusted performance ratios. In identifying the 'ideal' set of ratios for the South African banking industry, this study also found that pure technical efficiency, the priceto-earnings ratio and the static omega ratio were able to explain up to an average of $83 \%$ of future banking share returns.

Conclusion: The study contributes to the field of portfolio management in that both riskadjusted performance ratios and non-financial measures can be used as short-term and longterm investment decision-making tools. Further to this, the ability to explain future returns to some extent implies that the South African banking industry may be time-varying-information efficient.

Keywords: Banking industry; data envelopment analysis; DEA; financial and non-financial measures; risk-adjusted performance ratios; South Africa.

\section{Introduction}

The capital asset pricing model (CAPM) has played a significant role in modern portfolio theory for decades. The innovative work of Sharpe (1964), Lintner (1965), Mossin (1966) and Black (1972) brought together a model that 'embodies a theory of what can be inferred about expected returns when markets are in equilibrium, homogeneous expectations prevail and when all investors pursue a mean-variance optimizing objective' (Van Rensburg \& Robertson 2003:7). However, literature has shown that there are several empirical contradictions of the so-called SharpeLintner-Black (SLB) model, brought about by the assumptions that expected returns are a positive linear function of market betas and that market betas are sufficient to describe the cross-section of expected returns (Fama \& French 1992). The most prominent contradiction of the SLB model is reported by Banz (1981), who found that the size effect contributes to the ability of market betas to explain the cross-section of average returns. Another contradiction can be found in the work of Bhandari (1988), who reported a positive relationship between average returns and leverage. Although the SLB model assumes that leverage risk should already be captured by the market beta, Bhandari (1988) found that including leverage in a model (which already accounts for market size and beta) improves the explanation of average share returns. Further studies also found evidence to support the book-to-market ratio $(\mathrm{B} / \mathrm{M})$; the price-to-earnings ratio $(\mathrm{P} / \mathrm{E})$; the return-on-equity ratio (ROE); the DuPont model to overcome the shortcomings of the ROE ratio (Berzkalne \& Zelgalve 2014; Traub 2001); the dividend yield (DY); the implied dividend growth rate; the cash-flow-to-price ratio; and the price-to-net asset value (NAV) ratio as additional 'blanket' proxies for unnamed risk factors that can enhance the explanation of average share returns (see, for example, Asness, Porter \& Stevens 2000; Auret \& Cline 2011; Auret \& Sinclaire 2006; Basiewicz \& Auret 2010; Basu 1983; Chan, Hamao \& Lakonishok 1991; Fama \& French 2017; Hoffman 2012; Hou, Karolyi \& Kho 2011; Johannes, Korteweg \& Polson 2014; Lakonishok, Shleifer 
\& Vishny 1994; Litzenberger \& Ramaswamy 1979; Rosenberg, Reid \& Lanstein 1985; Soliman 2008; Stattman 1980; Van Rensburg 2001; Van Rensburg \& Robertson 2003; Zaremba \& Czapkiewicz 2017).

However, the studies of Chen and Shimerda (1981) and Pech, Noguera and White (2015) argue that financial ratios tend to comprise overlapping information, which make the suitability of a small representative group of ratios possible, but to establish such an 'all-inclusive' group remains an enormous challenge. Delen, Kuzey and Uyar (2013) attempted to address this problem by evaluating the underlying dimensions of several ratios and found that the net profit margin and earnings before tax-to-equity ratio possess the most promise for predicting future performance. The results from surveys conducted by Gibson (1987) and Matsumoto, Shivaswamy and Hoban (1995) contradict these findings. They report that security analysts and financial analyst charter-holders consider profitability and valuation ratios to be more insightful. Conversely, Pech et al. (2015) reported a wider range of ratios, pointing out that the DY, $\mathrm{P} / \mathrm{E}$ and the ROE ratio are some of the ratios that are more frequently used by equity analysts. Nevertheless, the study of Clark (1997) considers financial ratios as being backwardlooking, lacking the ability to reflect long-term and future consequences of managerial actions. This may be due to: their reliability on internal historical data and the sensitivity to manipulation (Van Heerden \& Heymans 2013), their being ineffective to represent the many facets of performance in general (Avkiran 1997), their inability to capture the interplay amongst the multiple resources and outputs of a company (Davenport \& Sherman 1987), and their failure to explain the reasons for 'good' or 'bad' performances (Avkiran 1997). To overcome these shortcomings, investors could typically consider the use of non-financial ratios as they are less exposed to manipulation, a more reliable source of information on firm failure, and better predictors of longterm performance (Ames et al. 2012; Kaplan \& Norton 1996; Johnson \& Kaplan 1987; Singleton-Green 1993).

Given this background, the main objective of this study is to determine to what extent bank efficiency, as a non-financial measure, outperforms: (1) financial (or, traditional accounting) and (2) risk-adjusted performance ratios to explain ex-post future share returns for the six largest South African banks from a momentum investment strategy perspective. The study of Jegadeesh and Titman (1993) found that past 'winners' on average continued to outperform past 'losers', which implies that there is momentum in share returns, to some extent, which can be exploited as documented by Fama (1991). For this study, this implies that the year-end rankings of each ratio at time $t$ is used to determine which of the top six South African banking shares will be more profitable over a one, three, and five year investment horizon. After each consecutive year the rankings of each ratio is compared to the ex-post realised and risk-adjusted banking share returns to determine which of the ratios is more efficient in explaining ex-post future performance and thus more ideal to utilise in a momentum investment strategy. Establishing which ratios are more consistent in explaining future performance can enable investors and portfolio managers to make more informed ex-ante decisions, using the more 'ideal' set of ratios as identified in this article. The scope of this study will, however, not include a comparative study of alternative momentum investment strategies, as the focus will be directed to determine only the most insightful ratios to use in the South African banking industry as future decision-making tools. Also, this study will only consist of an ex-post analysis and will not include any form of forecasting (ex-ante analysis).

The modelling flexibility of data envelopment analysis (DEA) and its ability to address both quantitative and qualitative data, as well as discretionary and nondiscretionary inputs (Golany \& Storbeck 1999), makes it most suitable for this study. The significance of this study is further emphasised by the limited research in this field. Only an estimated $1.63 \%$ of all DEA application papers have been applied in the field of investment management (Liu et al. 2013). In this study the goal of the DEA model will be twofold. Firstly, it is utilised to estimate three different forms of bank efficiency scores from the historical DI900 reports that were converted to BA900 reports by the South African Reserve Bank (SARB 2017a). These efficiency scores incorporate the internal operations of a banks and entail pure technical efficiency, scale efficiency, and total technical efficiency (which is a combination of scale and pure technical efficiency). Secondly, the same non-parametric, non-stochastic, mathematical programming approach is used to determine the ability of these bank efficiency scores to explain ex-post future banking share returns, along with that of other selected financial and risk-adjusted performance ratios. The DEA model's ability to acknowledge the interdimensional relationships (Cooper, Seiford \& Tone 2007) between the selected ratios and the ex-post future realised share returns for banks further reinforces its applicability as an investment decision-making tool and is therefore deemed appropriate for a study of this nature.

The structure of this article is as follows: section two provides a brief overview of the South African banking industry and, specifically, highlights the benefits of this industry as an investment option; section three provides an overview of the concept of relative bank efficiency and the general DEA model; section four provides a discussion on the methodology adopted in the study; section five reports the findings; finally, section six provides the conclusion and recommendations.

\section{The South African banking industry Structure and performance}

The South African banking industry has changed substantially since especially 2001, when the number of registered banks equalled 41, which has subsequently fallen to 17 by the end of 2016 (SARB 2016). After the September 2001 terrorist attacks in the United States (US), global uncertainty had a particularly profound impact on the South African banking industry, as many smaller banks either lost their licences or merged with larger South African universal banks (Stemmet 2016). As such, 
as of 2017 the South African banking industry was characterised by having four dominant universal bank holding companies, namely Barclays Africa Group Ltd (functioning under ABSA bank), the FirstRand Group Ltd (which includes the banks First National Bank - FNB Wesbank and Rand Merchant Bank - RMB), the Standard Bank Group Ltd, and the Nedbank Group Ltd. These socalled Big Four had a combined market share of approximately 83\% in 2017 (SARB 2017b). Investec Bank Ltd, which has a dual listing on both the London Stock Exchange and the Johannesburg Stock Exchange (JSE), is a high net worth specialist bank and the fifth largest according to asset size. Capitec Bank Ltd has in recent years entered the retail banking environment and shown tremendous growth. In September 2017, it had surpassed Nedbank in size according to market capitalisation and held the second-largest number of retail clients of all South African banks (Bonorchis 2017b; Businesstech 2017). The growth of Capitec Bank Ltd has seen unprecedented levels since its February 2002 listing on the JSE, where it had gained over $50000 \%$ as at August 2017 (Bonorchis 2017a).

Although the South African banking industry is highly concentrated with predominantly four large banks, by no means is the industry as a whole large in global terms. With total assets of approximately R4.9 trillion at the beginning of 2017 (SARB 2017b), the total assets-to-GDP-ratio has exceeded $100 \%$ consistently in recent years (Stemmet 2016). For banks individually, in 2014 it was estimated that the largest South African bank, the Standard Bank Group, was approximately 20 times smaller than the largest bank in the world (ICBC) according to assets, 18 times smaller according to equity, and employed almost ten times fewer the number of personnel (Coetzee 2016). Although small in global terms, the industry as a whole is, however, well capitalised. For example, due to strict compliance requirements to the Basel Capital standards, the average total capital adequacy ratio (CAR) as of January 2017 was 15.9\% (SARB 2017b). On an individual bank level, the common equity tier one (CET1) CAR ratio and the total CAR ratios are provided in Table 1 for the six largest bank holding groups in South Africa. The table also provides the most recent Basel III requirements relating to the leverage ratio and the liquidity coverage ratio.

The CET1 ratios for all six banks are well above the minimum South African requirements of $6.88 \%$ for year-end 2016, and the total capital ratios also exceed the minimum requirement of $10.38 \%$. The leverage ratios also exceed the minimum of $4 \%$ set by the SARB and the liquidity coverage ratios (LCRs) are above the 2016 requirement of $70 \%$. Overall, the South African banking industry is well capitalised and complies with the Basel III requirements driving the international regulatory agenda for banks (SARB 2017b).

\section{The regulation and soundness of South African banks}

The South African banking industry is regarded as one of the best regulated in the world. The World Economic Forum's Global Competitiveness Report (GCR), for example, rates the soundness of South African banks as consistently being in the top 10 globally since 2009. Table 2 reports the global competitiveness of five selected indicators provided by GCR that relate specifically to the South African banking industry and the JSE. Clearly, the banking industry is very competitive, and the soundness of banks in particular, suggests well-capitalised banks, that have been shown to be resilient to global systemic shocks, especially since the advent of the global financial crisis.

As of the end of 2017, South African banks were regulated by the Banking Supervision Department (BSD) at the South African Reserve Bank (SARB). However, the regulatory and supervisory environment is set to change in the next few years towards the so-called Twin Peaks Framework, which focuses on separating prudential and market conduct regulation and supervision: the former will be governed by the Prudential Authority (PA) and the latter by the Financial Sector Conduct Authority (FSCA) (Coetzee \& De Beer 2016). The so-called Financial Stability Oversight Committee (FSOC) will also be established to provide systemic oversight in the financial sector at large. These changes have been proposed amid the regulatory challenges post the global financial crisis of 20072009 throughout the world. More specifically, Twin Peaks is 'intended to provide a streamlined system of licensing, regulating and supervising financial institutions, whilst at the same time providing a new approach to the enforcement of financial regulation, supervision, client complaints (including a revised ombud scheme), client advice and financial (literacy) education' (Coetzee \& De Beer 2016:74).

The Financial Sector Regulation (FSR) Bill of 2015 is set to be the legislation used by regulators to enforce the Twin Peaks

TABLE 1: Selected regulatory indicators according to Basel III for the top six South African banks for year-end 2016.

\begin{tabular}{llcccc}
\hline Banks & Source & CET1 CAR (\%) & Total CAR (\%) & Leverage ratio (\%) & Liquidity coverage ratio (\%) \\
\hline Barclays Africa Group Ltd & Barclays Africa Ltd 2016 & 12.10 & 14.80 & 7.10 \\
Capitec Bank Holdings Ltd & Capitec Bank Ltd 2017 & 30.80 & 33.90 & 58.00 \\
FirstRand Ltd & Firstrand Ltd 2016 & 13.90 & 16.90 & $1152.00 \dagger$ & 9.00 \\
Investec Ltd & Investec Ltd 2017 & 9.90 & 14.10 & 7.40 \\
Nedbank Group Ltd & Nedbank Ltd 2016 & 12.10 & 15.30 & $7.30 \%$ \\
Standard Bank Group Ltd & Standard Bank Group Ltd 2016 & 13.90 & 16.60 & 6.50 \\
\hline
\end{tabular}

Note: Please see the full reference list of the article, Van Heerden, C. \& Coetzee, J., 2019, 'Re-examining the ability to explain future South African banking share returns: A data envelopment analysis approach', South African Journal of Economic and Management Sciences 22(1), a2852. https://doi.org/10.4102/sajems.v22i1.2852, for more information.

$\dagger$, The value for Capitec Bank Ltd is substantially higher than that of the other banks due to the conservative liquidity management approach adopted by the bank. This is primarily due to the bank relying solely on retail deposit funding (Capitec Bank Ltd 2017); $\$$, The group figures for Investec are not provided for this indicator. As such, the data for the South African operations is provided; $\S$, This amount equals the three-month average for Investec Bank Ltd.

CET1, common equity tier; CAR, capital adequacy ratio. 
TABLE 2: The global competitiveness of the South Africa's banking industry.

\begin{tabular}{|c|c|c|c|c|c|c|}
\hline Year & Source & $\begin{array}{l}\text { Availability of financial } \\
\text { services }\end{array}$ & $\begin{array}{l}\text { Affordability of } \\
\text { financial services }\end{array}$ & $\begin{array}{l}\text { Ease of access to } \\
\text { loans }\end{array}$ & $\begin{array}{c}\text { Soundness of } \\
\text { banks }\end{array}$ & $\begin{array}{c}\text { Regulation of securities } \\
\text { exchanges }\end{array}$ \\
\hline $2008 / 2009$ (out of 134 ) & World Economic Forum (2008) & $12 \dagger$ & - & 31 & 15 & 5 \\
\hline 2009/2010 (out of 133) & World Economic Forum (2009) & $6 \dagger$ & - & 31 & 6 & 2 \\
\hline 2010/2011 (out of 139) & World Economic Forum (2010) & 7 & 43 & 41 & 6 & 1 \\
\hline $2011 / 2012$ (out of 142 ) & World Economic Forum (2011) & 3 & 39 & 36 & 2 & 1 \\
\hline $2012 / 2013$ (out of 144 ) & World Economic Forum (2012) & 2 & 22 & 30 & 2 & 1 \\
\hline $2013 / 2014$ (out of 148 ) & World Economic Forum (2013) & 2 & 13 & 22 & 3 & 1 \\
\hline $2014 / 2015$ (out of 144 ) & World Economic Forum (2014) & 6 & 21 & 32 & 6 & 1 \\
\hline 2015/2016 (out of 137) & World Economic Forum (2015) & 6 & 21 & 32 & 8 & 2 \\
\hline 2016/2017 (out of 138) & World Economic Forum (2016) & 2 & 27 & 12 & 2 & 3 \\
\hline
\end{tabular}

Note: Please see the full reference list of the article, Van Heerden, C. \& Coetzee, J., 2019, 'Re-examining the ability to explain future South African banking share returns: A data envelopment analysis approach', South African Journal of Economic and Management Sciences 22(1), a2852. https://doi.org/10.4102/sajems.v22i1.2852, for more information.

$\dagger$, The indicator was labelled 'Financial market sophistication' for the respective year.

framework. The FSR is also set to provide clear guidelines for regulators regarding the systemic risk and financial stability facing South African banks (SARB 2017b). This macroprudential approach to regulation is at the core of the future regulatory approach adopted by both the PA and the FSCA and is aligned to global best practices. Twin Peaks will therefore provide a total revamp of the regulatory environment for the South African financial sector. Overall, the South African banking industry is well regulated and capitalised and is regarded as one of the most sound in the world. These features suggest an environment that encourages future investment into the industry.

\section{Relative efficiency and the general data envelopment analysis model}

The literature provides no consensus regarding which method is more appropriate in measuring bank efficiency (Titko, Stankevičienè \& Lāce 2014). The traditional approach mostly considered applying traditional financial ratios, but it is considered to provide unreliable results as these ratios are unable to capture the complex financial environment and all the activities of a bank (Arshinova 2011; Yang 2009). Despite that, the study of Mester (2003) also argues that efficiency measurement can be thought of as only one aspect of firm performance. Nevertheless, to overcome the shortcomings of using traditional financial ratios, frontier approaches were introduced which are able to incorporate multiple inputs and outputs (Titko et al. 2014). This new approach of measuring efficiency was initiated by studies like that of Debreu (1951), who demonstrated the comprehensive quality of using a resource utilisation coefficient, and Koopmans (1951), who introduced the concept of an efficient point. However, the novel work by Farrell (1957) demonstrated how to measure efficiency in practice and was the first to recommend that the level of efficiency be measured by means of an equiproportionate reduction in current inputs to produce predetermined levels of outputs. This can be accomplished by means of either a non-parametric, non-stochastic, mathematical programming framework (Charnes, Cooper \& Rhodes 1978), or a parametric, stochastic, statistical framework (Aigner, Lovell \& Schmidt 1977; Meeusen \& Van Den Broeck 1977). The latter includes the stochastic frontier analysis (SFA), which constructs a smooth parametric frontier that considers stochastic noise in the data and allows for hypothesis testing regarding production structures and the degree of inefficiency (Hossain et al. 2012; Jacobs 2001). However, the need to impose an explicit parametric form for the underlying technology and an explicit distributional assumption for the inefficiency term makes this a less flexible model (Sharma, Leung \& Zaleski 1999). To deal with this, Charnes et al. (1978) introduced a suitable alternative that entails a non-parametric, nonstochastic, mathematical programming framework called the DEA model. This model was originally introduced under a limited constant returns-to-scale (CRS) perspective, which generalises 'the single-output to single-input classical engineering-science ratio definition to multiple outputs and inputs without requiring preassigned weights' (Banker, Charnes \& Cooper 1984:1078). Inspired by the work of Allen (1939) and Shephard (1953; 1970), which considered the possibility of increasing, decreasing or constant returns to scale in multiple input and output scenarios, Banker et al. (1984) improved on the CRS perspective by introducing a variable returns to scale (VRS) perspective, which accounts for possibilities such as capacity limitations on inputs. Under both CRS and VRS, the DEA model has the ability to solve linear programming (LP) problems that generate a nonparametric, piecewise-linear, convex frontier (Färe, Grosskopf $\&$ Lovell 1985). This enables the measurement of relative or comparative efficiency in terms of the inputs and outputs of a decision-making unit (DMU) (or in the case of this study, banks) by benchmarking the non-best practices with best practices in order to determine the extent of inefficiencies (Avkiran 1999; Jaforullah \& Whiteman 1999). Although the DEA model does not address the problem of output assessment, it seeks to combine multiple inputs and outputs in a single, non-arbitrary, non-subjective manner via the criterion of Pareto efficiency without requiring specification of any a priori weights (Nunamaker 1985). Nevertheless, the results derived from the DEA model are still sensitive to the selection of inputs and outputs (Kumar \& Singh 2014), emphasising the importance of selecting the correct inputs and outputs.

The significance of the DEA model can be emphasised by its vast application. For example, in the health care sector (Nunamaker 1983; Omrani, Shafaat \& Emrouznejad 2018; Worthington 2004), in the agricultural sector (Iglesias, Castellanos \& Seijas 2010; Kuhn et al. 2018), in the transportation sector (Azadeh, Ghaderi \& Maghsoudi 2008; 
Barak \& Dahooei 2018; Schefczyk 1993), in the education sector (Aparicio et al. 2018; Bessent et al. 1982), in the tourism sector (Barros \& Dieke 2008; Cheng, Lu \& Chung 2010; Van Heerden \& Saayman 2018), in the industrial sector (Fang, Wu \& Zeng 2009; Sueyoshi, Goto \& Ueno 2010; Wang \& Zhang 2018), in the communication sector (Giokas \& Pentzaropoulos 2008; Hu et al. 2018; Resende \& Façanha 2005), in the energy sector (Azadeh et al. 2008; Shi, Bi \& Wang 2010; ZuranoCervelló et al. 2018), in local government (Afonso \& Fernandes 2008; Van Heerden \& Rossouw 2014; Xia et al. 2018), in the sport industry (Boscá et al. 2009; Roboredo, Aizemberg \& Meza 2015), in the real estate sector (Anderson et al. 2002; Isik \& Topuz 2017; Topuz, Darrat \& Shelor 2005), in the construction industry (Hu \& Liu 2018; Tsolas 2011; Xue et al. 2008), in the manufacturing sector (Halim 2010; Liu 2008; Mahadevan 2002), in the retail sector (Kahraman et al. 2018; Xavier, Moutinho \& Moreira 2015), in the insurance sector (Barros, Nektarios \& Assaf 2010; Eling \& Jia 2018; Wanke \& Barros 2016), and in the banking sector (Quaranta, Raffoni \& Visani 2018; Sherman \& Gold 1985; Van Heerden \& Van Der Westhuizen 2008). However, the significance of this study can be emphasised by the limited research in investment management. The only existing literature in this field includes, amongst others, the use of DEA as a portfolio selection criterion (Dia 2009; Edirisinghe \& Zhang 2008; Huang et al. 2015; Joro \& Na 2006; Mashayekhi \& Omrani 2016; Pätäri, Leivo \& Honkapuro 2010, 2012), to measure portfolio efficiency in a mean-variance framework (Liu et al. 2015), to evaluate fund managers' efficiency (Banker, Chen \& Klumpes 2016), as a mutual fund performance assessor (Abad, Thore \& Laffarga 2004; Alexakis \& Tsolas 2011; Basso \& Funari 2016; Chen 2008; Kuosmanen 2007), to evaluate portfolio risk in the forex spot market (Amiri et al. 2010), to evaluate the link between bank efficiency and share performance (Beccalli, Casu \& Girardone 2006; Sufian \& Majid 2007), to evaluate the relationship between portfolio diversification and efficiency (Choi \& Min 2017), as a complementary share performance tool to the traditional set of fundamental factors (Van Heerden \& Heymans 2013), as an investment tool to predict Japanese bank share performance (Avkiran \& Morita 2010), and to evaluate an investment fund's or portfolio's performance (Lim, Oh \& Zhu 2014; Tarim \& Karan 2001).

From the literature it is clear that the popularity of the DEA model can be motivated by its flexibility, as it is capable of handling non-commensurate multiple inputs and outputs simultaneously (Kirigia, Sambo \& Scheel 2001; Nunamaker 1985). Its estimators are considered to be consistent, able to converge faster than estimators from other frontier methods, and unbiased, with the assumption of no underlying model or reference technology (Grosskopf 1996; Kittelsen 1999). The DEA model is also able to uncover relationships that are unknown to other methodologies (Kumar \& Singh 2014). Furthermore, the efficiency scores generated from the DEA model enable the characterisation of resource utilisation (Førsund \& Hjalmarsson 1974), which is grounded on an initial set of objectives (Mester 1993). The scope of this study will, however, be limited to focusing on only two elements of X-efficiency, namely technical and scale efficiency. X-inefficiency as a whole implies that banks are either wasting their inputs (that is, they are technically inefficient), or using the wrong combination of inputs (they are allocatively inefficient), or both (Mester 2003). The inappropriate usage of the capacity size (too small or too large) can also be a contributing factor to total technical inefficiency. This is commonly referred to as scale inefficiency and can take on two forms, namely increasing returns to scale (IRS) or decreasing returns to scale (DRS). If the scale of the operation is considered to be too small and must be expanded in order to improve efficiency, the economies of scale are characterised as being IRS. However, when the scale of operation is too large and must decrease in order to improve efficiency, it is characterised as being DRS (Zere et al. 2006). In the estimation process an input-orientated or outputorientated approach can be executed under a CRS or a VRS perspective. The input-orientated approach will characterise the production technology of a DMU for producing a given output mix with the minimum inputs, whereas an outputorientated approach will characterise a DMU in pursuit of producing the maximum output bundle with the given inputs mix (Coelli, Rao \& Battese 1998).

In order to determine the level of efficiency in which ratios explain future share returns, this study will adopt an inputorientated approach. Using this approach with a VRS perspective will result in outputs increasing or decreasing disproportionally when the inputs increase; conversely, with a CRS perspective, outputs will increase proportionally owing to an increase in inputs (Avkiran 1999). However, the CRS perspective will not function properly under conditions such as imperfect competition and constraints on finance that limit DMUs, and in this case banks, from operating at their optimal scale (Coelli et al. 1998). Despite this, it is still recommended that the DEA model be estimated separately under both the CRS and VRS perspectives and then compared in terms of the generated efficiency scores (Coelli et al. 1998): the efficiency scores generated from the VRS perspective represent pure technical efficiency that measures efficiency without scale efficiency, whereas the efficiency scores generated from the CRS perspective represent technical efficiency that measures the inefficiencies resulting from the size of operations and input-output combinations (Avkiran 1999). The difference between the VRS efficiency and CRS efficiency scores represents a potential scale inefficiency measurement. To determine the economies of scale, an additional model must be estimated with a nonincreasing return to scale (NIRS) perspective. By comparing the technical efficiency scores of the NIRS perspective with those of the VRS perspective, it can be determined if banks are operating at decreasing or increasing returns to scale (Coelli et al. 1998). If these models generate efficiency scores that are the same, it will be an indication that banks are operating at decreasing returns to scale. However, if the efficiency scores of the VRS perspective and of the NIRS model differ, increasing returns to scale exist. 


\section{Methodology and data The multi-stage DEA model}

This study utilises the multi-stage DEA model, which is estimated using the DEAFrontier software, a DEA add-in for Microsoft Excel ${ }^{\circledR}$ developed by Zhu (2016). In this model, consider $K$ to be the number of inputs and $M$ the number of outputs on each of $N$ banks, where for the $i$ th banks these inputs and outputs are represented by the vectors $x_{i}$ and $y_{i}$. The $M \times N$ output matrix is represented by $Y$, and the $K \times N$ input matrix by $X$. The constant returns to scale, inputorientated, multi-stage DEA model can thus be illustrated by the following steps provided by Coelli (1998), with minor changes to this approach when applying a variable returns to scale approach:

First, conduct a radial LP process with the following form:

$\min \theta$

$\theta, \lambda$

s. t. $-y_{i}+Y \lambda \geq 0$,

$\theta \mathrm{x}_{\mathrm{i}}-X \lambda \geq 0$,

$\lambda \geq 0$,

[Eqn 1]

$\theta$ is a scalar and $\lambda$ denotes a $N \times 1$ vector of constants. This process is continued $N$ times, generating a $\theta$ for each of the banks.

Second, this process is followed by a second-stage LP process in which the sum of any remaining slacks is maximised, illustrated as follows:

$\max \left(M 1^{\prime} O S+K 1^{\prime} I S\right)$

$\lambda, O S, I S$

s. t. $-y_{i}+Y \lambda-O S=0$

$c x_{i}, X \lambda-I S=0$,

$\lambda \geq 0, O S \geq 0, I S \geq 0$,

[Eqn 2]

$c x_{i}$ denotes the input vector of the $i$ th banks, which has been multiplied by $\theta$ (being contracted) from Step 1; OS denotes the $M \times 1$ vector of output slacks; IS denotes the $K \times 1$ vectors of input slacks; and $K 1$ and $M 1$ are $K \times 1$ and $M \times 1$ vectors of ones. This process is continued $N$ times, after which all the banks with no slacks and those who have a technical efficiency score of $\theta=1$ are identified and classed as 'efficient banks'. This process is also duplicated for all banks with nonzero slack variables, after which they are classified as the 'banks with slacks' set. The 'banks with slacks' set is then used to estimate a sequence of radial movements based on projected points estimated in Step 1 in order to obtain the projected point on the efficient frontier. Conversely, the 'efficient banks' will be used only as a reference in the LP estimations from this stage forward.

Third, a sequence of $K$ LPs is conducted in order to identify all input dimensions that consist of slacks of the $i$ th banks in the 'banks with slacks' set. This step will, however, break down if some inputs are found to be zero. In this process, each LP will allow contractions in only one of the inputs, which will determine the presence of potential slacks within these inputs. The LP for the jth input of the ith bank can be illustrated as follows:

$\min \theta$

$\theta, \lambda$

s. t. $-y_{i}+Y_{e} \lambda \geq 0$,

$\theta c x_{i}^{j}-X_{e}^{j} \lambda \geq 0$

$c x_{i}^{\neq j}-X_{e}^{\neq j} \lambda \geq 0$,

$\lambda \geq 0$,

[Eqn 3]

$c x_{i}^{j}$ denotes the $j$ th input of the $i$ th bank, which is multiplied by $\theta$ (being contracted) that is obtained from Step $1, X_{e}^{j}$ denotes the $1 \times N_{e}$ vector of the $j$ th input of all the efficient banks, and $c x_{i}^{\neq j}$ denotes the $(K-1) \times 1$ vector of inputs of the $i$ th bank. This excludes the $j$ th input, which is then contracted by being multiplied by $\theta$, as obtained in Equation 1. $X_{e}^{\neq j}$ denotes the $(K-1) \times N_{e}$ matrix of inputs of all the efficient banks, also excluding the $j$ th input, $N_{e}$ denotes the number of efficient banks as already identified in Step 2, $Y_{e}$ denotes the matrix of outputs of the efficient banks, and $\lambda$ has a dimension of $N_{e} \times 1$.

Fourth, an LP is estimated for the $i$ th bank in the 'banks with slacks' set, which seeks a radial reduction in all inputs that have already been identified during Step 3 as having potential slacks. This estimation can be illustrated as follows:

$\min \theta$

$\theta, \lambda$

s. t. $-y_{i}+Y_{e} \lambda \geq 0$,

$\theta c \mathrm{x}_{i}^{s}-X_{e}^{s} \lambda \geq 0$

$c x_{i}^{n s}-X_{e}^{n s} \lambda \geq 0$,

$\lambda \geq 0$,

[Eqn 4]

$s$ denotes the subset of inputs that have potential slacks, and $n s$ denotes the remainder of the inputs used. Remember that the radial reduction in this specific step starts by applying the projected point $\left(y_{e^{\prime}} c x_{i}\right)$ that has already been estimated during Step 1.

Fifth, it is still possible for some input slacks to remain after the radial reduction in the previous step. To overcome this problem, Steps 3 and 4 must be repeated with the projected point (which has already been identified during Step 4) until no remaining input slacks are present.

Finally, a radial expansion is conducted in the output slack dimensions until no output slacks remain. This can be accomplished by taking the projected points of the $i$ th bank (as estimated in Step 5) and repeating Steps 3 through to 5. The final projected point from this step (which will be invariant to the units of measurements that were chosen) will be on the efficient surface. The slacks can then be estimated by subtracting the final projected point in this step from the projected point that was obtained in Step 1. Also, the peers of the $i$ th bank can be identified from the $\lambda$ vector of the final projected point.

The benefit of using a multi-stage DEA model is that it has the ability and advantage to focus on each bank individually, 
relative to sample averages or parametric populations. The model can thus adjust for exogenous variables that are beyond the control of DMUs and accommodate multiple inputs and outputs without the need for homogeneous measurement units. It also does not require any assumptions of a functional form relating inputs to outputs and can focus on observed best-practice frontiers rather than on central tendency properties of frontiers. Furthermore, it provides insight into the input and output quantities that inefficient banks must achieve in order to operate on the efficient frontier and it produces a single efficiency estimate for each bank in terms of its respective input-output relationships (Charnes et al. 1978; Nunamaker 1985). The multi-stage DEA version is therefore appropriate for this study, as it overcomes two main shortcomings of the commonly used two-stage LP process (Coelli 1998; Lovell \& Pastor 1995): firstly, the twostage LP process maximises the sum of slacks, where it should minimise it, and it identifies the furthest efficient point, where it should identify the nearest point; secondly, the two-stage LP process is not invariant to the units of measurement.

\section{Sampling and data selection}

The data used for this study included annual financial ratios obtained from the IRESS INET (2017) database spanning from 2004 to 2016 (see Table 3). The implied dividend growth rate and the equally weighted DuPont were estimated in Microsoft Excel ${ }^{\circledR}$. As the ROE fails to account for financial leverage, a DuPont index was constructed, where equal weights were assigned to financial leverage, return on assets, and the ROE. The implied dividend growth rate was estimated by multiplying the retention rate with the ROE, as obtained from the IRESS INET (2017) database. Furthermore, monthly closings prices for Barclays Africa Group Ltd (BGA), Capitec Bank Holdings Ltd (CPI), Firstrand Ltd (FSR), Investec Ltd (INL), Nedbank Group Ltd (NED) and Standard Bank Group Ltd (SBK) were sourced from the IRESS INET (2017) database for the period 31 January 2004 to 31 December 2016. This time span was determined by the data availability at the time of the study. The monthly share returns and market capitalisation derived from these closing prices were adjusted for splits and dividends, accordingly, before being converted to an annual average. The monthly returns were estimated as follows: $\left(\right.$ Price $_{t}-$ Price $\left._{t-1}\right) \div$ Price $_{t-1}$.
The JSE Bank index (J835) was utilised as the market proxy and was also sourced from the IRESS INET (2017) database. Based on the findings and arguments posed by Van Heerden (2016) and Grandes and Pinaud (2004), this study uses the 3-month Negotiable Certificates of Deposits (NCDs) rate as the risk-free rate proxy and the threshold proxy for the static Omega ratio, which was sourced from the SARB website (2017a). Owing to the unavailability of data, transaction costs were excluded.

A list of the typically most popular risk-adjusted performance ratios and measures used in this study is provided in Table 3. Jensen's alpha (Jensen 1968) is included to evaluate the predictive ability of the market beta over the time horizon under evaluation. Further to this, in order to account for higher moments and correlation in returns, the Sharpe ratio is adjusted to account for value-at-risk (VaR), conditional expectation of loss (CVaR), and the implementation of the Cornish-Fisher expansion (MVaR). Finally, as with the works of Elyasiani and Mehdian (1990), Kaparakis, Miller and Noulas (1994) and Wheelock and Wilson (1995), this study will adopt an intermediation approach (Sealey \& Lindley 1977) in the selection of input and output variables for the estimation of pure technical (VRS), scale, and total technical efficiency (CRS). Listed in Table 4, these input and output variables for the period January 2004 to December 2016 were obtained from the historical DI900 reports that were converted to BA900 reports on the SARB website (2017a). The monthly total of each variable (which also forms the main entries in the financial return statements) is used as reported in the BA900 statements (see column 2 in Table 4), with the only exception being the deposits, loans and advances output variable which excludes SA group financing (item \#111), and was used as an input variable.

\section{Results}

The results on the average ability of each ratio (across all six banks) to explain ex-post future share returns over a one-, three- and five-year investment horizon are depicted in Figure 1. On average, pure technical efficiency (VRS) was able to explain $94 \%$ (the highest) of the ex-post future share returns over all three investment horizons under evaluation.

TABLE 3: The financial, non-financial and risk-adjusted performance ratios and measures under evaluation.

\begin{tabular}{lll}
\hline Financial ratios & Non-financial measures & Risk-adjusted performance ratios \\
\hline Dividend yield (\%) & Pure technical efficiency (VRS) & Sharpe ratio (Sharpe 1966) \\
Earnings yield (\%) & Scale efficiency & Treynor ratio (Treynor 1965) \\
Book-to-market ratio & Total technical efficiency (CRS) & Jensen's alpha (Jensen 1968) \\
Cash-flow-to-price ratio & - & Sortino ratio (Sortino \& Van Der Meer 1991) \\
Price-to-earnings ratio & - & Calmar ratio (Young 1991) \\
Price-to-NAV ratio & - & VaR(99\%)-Sharpe ratio (adapted from Dowd 1999, 2000) \\
Return-on-equity ratio (\%) & - & Conditional [CVaR(99\%)] Sharpe ratio \\
Market capitalisation & - & (adapted from Artzner et al. 1997, 1999; Esfahanipour \& Mousavi 2011) \\
Implied dividend growth rate & - & Modified [MVaR(99\%)] Sharpe ratio \\
Equally weighted DuPont & - & (adapted from Favre \& Galeano 2002; Gregoriou \& Gueyie 2003) \\
\hline
\end{tabular}

Note: Please see the full reference list of the article, Van Heerden, C. \& Coetzee, J., 2019, 'Re-examining the ability to explain future South African banking share returns: A data envelopment analysis approach', South African Journal of Economic and Management Sciences 22(1), a2852. https://doi.org/10.4102/sajems.v22i1.2852, for more information.

VRS, variable returns to scale; CRS, constant returns to scale; NAV, net asset value; VaR, value at risk; CVaR, conditional value at risk; MVaR, Modified value at risk. 
Total technical efficiency (CRS) exhibited the second best performance in explaining an average of $91 \%$ of ex-post future share returns over the three- and five-year investment horizon. Scale efficiency exhibited the second best ability to explain one-year-ahead share returns (92\%) and the third best ability to explain ex-post future share returns over the threeand five-year investment horizon $(90 \%$ on average for both periods). Conversely, market capitalisation exhibited the poorest ability to explain ex-post future returns over all three investment horizons under evaluation (34\% on average), followed by the equally weighted DuPont index $(41 \%$ on average) and the VaR-Sharpe ratio (43\% on average), with their poor ability to explain one-, three- and five-years-ahead share returns (ex-post). The financial ratio that exhibited the best performance over all three investment horizons under evaluation was the $\mathrm{P} / \mathrm{E}$ ratio ( $82 \%$ on average), which supports the findings of Van Rensburg and Robertson (2003). Other top-performing financial ratios include the ROE ratio (76\% on average), the EY (69\% on average), and the implied dividend growth rate $(65 \%$ on average).

The results reported in Figure 1 (and Table 1-A1 in the appendix) contradict the findings of Fama and French (2017),

TABLE 4: Selected input and output variables for estimating technical and scale efficiency.

\begin{tabular}{lc}
\hline Variables & Item number \\
\hline Input & 1 \\
Total deposits & 103 \\
Central bank and money & 111 \\
SA group financing & 96 \\
Total equity & \\
Output & 110 \\
Deposits, loans and advances & 80 \\
Other liabilities & 195 \\
Investment and bills &
\end{tabular}

Note: The scale of some of these variables had to be adjusted to accommodate negative values.
Muller and Ward (2013), and Van Rensburg and Robertson (2003) from a specifically banking industry point of view. More specifically, the EY (69\% on average), cash-flow-to-price ratio ( $64 \%$ on average), $\mathrm{B} / \mathrm{M}$ ratio $(60 \%$ on average), and the market capitalisation ( $34 \%$ on average) performed relatively poorly and were inconsistent in explaining ex-post future returns over the different investment horizons. It is also interesting to note that the composition of the best performing financial ratios differed amongst the three investment horizons. Although the $\mathrm{P} / \mathrm{E}$ and return-to-equity ratios exhibited the best performance throughout all three investment horizons, the rest of the composition for each investment horizon differed. The other three top-performing ratios over the one- and three-year investment horizon entailed the earnings yield, cash-flow-to-price ratio and the implied dividend growth rate, whereas the implied dividend growth rate, price-to-NAV ratio and the earnings yield were the other three top-performing ratios over the five-year investment horizon. These results imply that passive and active portfolio managers may consider different financial ratio compositions. The implication is that the most 'ideal' set of ratios will be influenced by the investment horizon, which to some extent may provide some explanation as to why past studies found different results (besides the fact that they might also be sector dependent). This time-dependency phenomenon was, however, not present with the evaluation of the risk-adjusted performance measures. The static Omega ratio exhibited the best performance in explaining ex-post future share returns over all three investment horizons under evaluation (71\% on average), followed by the Treynor ratio ( $54 \%$ on average), the Calmar ratio ( $53 \%$ on average), the Sharpe ratio (53\% on average), and the Jensen's alpha (52\% on average). This implies that risk-adjusted performance ratios (including non-financial measures) can be used, to some extent, as a short- and long-term investment decisionmaking tool. However, the worst performing risk-adjusted

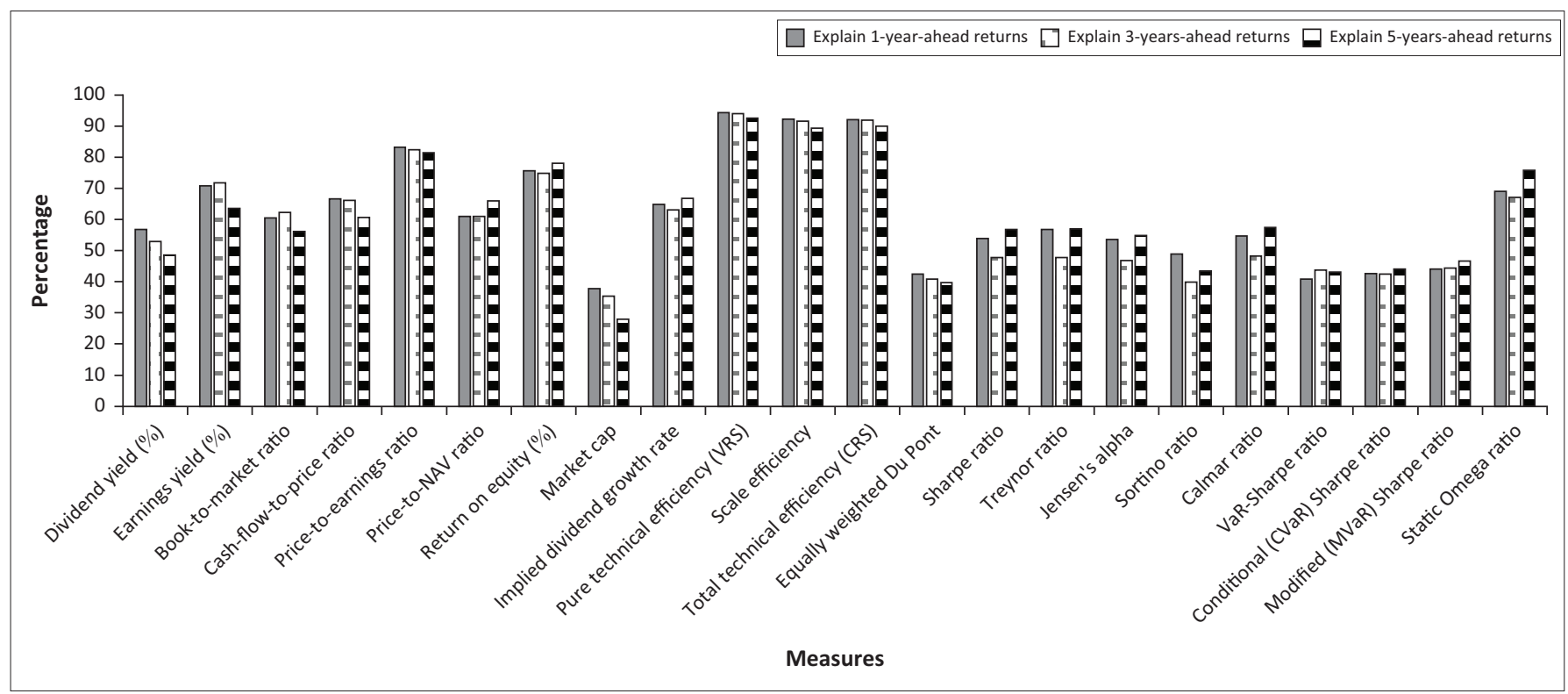

Note: See Table 1-A1 in Appendix 1 for a more detailed report.

FIGURE 1: Average ability to explain future returns (across all banks). 
performance ratios over the three investment horizons consisted of the Sortino ratio ( $44 \%$ on average) and the different modified Sharpe ratios, which entailed the MVaRSharpe ratio ( $45 \%$ on average), the CVaR-Sharpe ratio (43\% on average), and the VaR-Sharpe ratio ( $43 \%$ on average). Overall, the results suggest that non-financial measures exhibit the highest average ability (92\%) to explain ex-post future share returns over all three investment horizons, followed by the financial ratios (61\% on average) and riskadjusted performance ratios (51\% on average). Nevertheless, there is also consistency found in the top-ranked measures (per category) over all three investment horizons under evaluation. These ratios entailed pure technical efficiency (94\% on average), the $\mathrm{P} / \mathrm{E}$ ratio ( $82 \%$ on average), and the static Omega ratio (71\% on average), where this group of measures would have enabled an investor to explain $82 \%$ (on average) of future returns over all three investment horizons.

Tables 5-7 further highlight the findings that non-financial measures had the highest success rate in explaining future returns of individual banking shares, over the one-, three-, and five-year investment horizons ( $83 \%, 83 \%$, and $67 \%$ on average). Pure technical efficiency (VRS) exhibited the best performance, followed by scale efficiency and total technical efficiency (CRS). The financial ratios outperformed the risk-adjusted performance ratios, with the $\mathrm{P} / \mathrm{E}$ ratio having the highest success rate followed by the ROE and price-to-NAV ratios. From the risk-adjusted performance ratios perspective, the static Omega ratio exhibited the best success followed by the Treynor and the Sharpe ratios. Of interest to note is that market capitalisation exhibited the worst success rate in explaining the ex-post future share returns of Firstrand Ltd, Standard Bank Group Ltd, and Nedbank Ltd over all three investment horizons under evaluation, except for Nedbank Ltd over the five-year investment horizon. The Sortino and CVaR-Sharpe ratios exhibited the poorest success rate in explaining the ex-post future share returns of Capitec Bank Holdings Ltd and Investec Bank Ltd, over all three investment horizons (see Tables 3-5). The only noteworthy exception was for Barclays Africa Group Ltd, where the P/E ratio exhibited the best success rate (as opposed to pure technical efficiency), whereas the equally weighted DuPont (over the one-year horizon) and market capitalisation (over the three- and five-year horizons) exhibited the poorest success rate. Furthermore, over the five-year investment horizon, there was no significant difference between the different ratios in explaining the ex-post future share returns of Capitec Bank Holdings Ltd. Also, the price-to-NAV ratio exhibited the best success rate in explaining the ex-post future share returns of Firstrand Ltd over all three investment horizons (see Tables 5-7).

These findings suggest that the non-financial measures, namely pure technical efficiency (VRS), scale efficiency, and total technical efficiency (CRS), outperformed the ability of financial and risk-adjusted performance ratios to explain ex-post future share returns for the six individual South African banking shares. It is also noteworthy to report

TABLE 5: Average explanatory ability of ratios to explain one year ahead share returns per bank.

\begin{tabular}{|c|c|c|c|c|c|c|}
\hline Ratios under evaluation & $\begin{array}{l}\text { Barclays Africa } \\
\text { Group Ltd (\%) }\end{array}$ & $\begin{array}{c}\text { Capitec Bank } \\
\text { Holdings Ltd (\%) }\end{array}$ & $\begin{array}{l}\text { Firstrand Ltd } \\
(\%)\end{array}$ & $\begin{array}{l}\text { Investec Ltd } \\
(\%)\end{array}$ & $\begin{array}{c}\text { Nedbank } \\
\text { Group Ltd (\%) }\end{array}$ & $\begin{array}{l}\text { Standard Bank } \\
\text { Group Ltd (\%) }\end{array}$ \\
\hline Dividend yield (\%) & 41.76 & 95.41 & 48.95 & 46.33 & 45.75 & 62.50 \\
\hline Earnings yield (\%) & 59.17 & 92.35 & 63.50 & 84.05 & 58.00 & 67.60 \\
\hline Book-to-market ratio & 51.19 & 92.49 & 69.58 & 49.79 & 44.06 & 56.23 \\
\hline Cash-flow-to-price ratio & 59.99 & 92.22 & 66.82 & 65.00 & 59.44 & 56.54 \\
\hline Price-to-earnings ratio & 92.41 & 81.58 & 83.35 & 74.49 & 87.49 & 80.05 \\
\hline Price-to-NAV ratio & 30.31 & 64.61 & 66.30 & 93.21 & 38.48 & 72.47 \\
\hline Return-on-equity (\%) & 64.58 & 86.97 & 58.11 & 88.28 & 84.04 & 71.82 \\
\hline Market cap & 18.61 & 95.81 & 15.98 & 66.90 & 14.43 & 14.92 \\
\hline Implied dividend growth rate & 66.10 & 77.52 & 54.48 & 74.12 & 61.80 & 55.10 \\
\hline Pure technical efficiency (VRS) & 91.58 & 96.75 & 92.78 & 95.13 & 99.09 & 90.56 \\
\hline Scale efficiency & 89.81 & 100.00 & 89.87 & 92.43 & 90.34 & 90.82 \\
\hline Total technical efficiency (CRS) & 88.27 & 98.67 & 89.43 & 92.41 & 95.87 & 87.89 \\
\hline Equally weighted DuPont & 12.13 & 62.84 & 67.30 & 54.17 & 26.50 & 31.64 \\
\hline Sharpe ratio & 43.51 & 68.90 & 47.90 & 60.62 & 56.16 & 45.89 \\
\hline Treynor ratio & 44.67 & 68.29 & 53.81 & 68.78 & 52.15 & 53.39 \\
\hline Jensen's alpha & 41.04 & 68.37 & 48.03 & 68.47 & 47.37 & 47.64 \\
\hline Sortino ratio & 37.93 & 59.23 & 45.67 & 55.19 & 46.89 & 48.49 \\
\hline Calmar ratio & 45.95 & 68.78 & 42.56 & 64.68 & 51.05 & 54.76 \\
\hline VaR-Sharpe ratio & 18.55 & 77.64 & 27.60 & 46.98 & 43.11 & 31.35 \\
\hline Conditional (CVaR) Sharpe ratio & 22.73 & 77.76 & 35.77 & 40.92 & 46.25 & 32.20 \\
\hline Modified (MVaR) Sharpe ratio & 23.44 & 77.05 & 36.33 & 48.49 & 46.24 & 32.86 \\
\hline Static Omega ratio & 66.25 & 72.34 & 64.76 & 76.33 & 68.53 & 65.94 \\
\hline Overall average & 50.45 & 80.71 & 57.68 & 68.49 & 57.41 & 56.85 \\
\hline Overall minimum & 12.13 & 59.23 & 15.98 & 40.92 & 14.43 & 14.92 \\
\hline Overall maximum & 92.41 & 100.00 & 92.78 & 95.13 & 99.09 & 90.82 \\
\hline Average of traditional financial ratios & 49.62 & 84.18 & 59.44 & 69.64 & 52.00 & 56.89 \\
\hline Average of non-financial measures & 89.89 & 98.47 & 90.70 & 93.32 & 95.10 & 89.76 \\
\hline Average of risk-adjusted performance ratios & 38.23 & 70.93 & 44.71 & 58.94 & 50.86 & 45.84 \\
\hline
\end{tabular}

VaR, value at risk; CVaR, conditional value at risk; MVaR, Modified value at risk. 
TABLE 6: Average explanatory ability of ratios to explain three years ahead share returns per bank.

\begin{tabular}{|c|c|c|c|c|c|c|}
\hline Ratios under evaluation & $\begin{array}{l}\text { Barclays Africa } \\
\text { Group Ltd (\%) }\end{array}$ & $\begin{array}{c}\text { Capitec Bank Holdings } \\
\text { Ltd (\%) }\end{array}$ & $\begin{array}{c}\text { Firstrand Ltd } \\
(\%)\end{array}$ & $\begin{array}{l}\text { Investec Ltd } \\
(\%)\end{array}$ & $\begin{array}{c}\text { Nedbank Group Ltd } \\
(\%)\end{array}$ & $\begin{array}{l}\text { Standard Bank } \\
\text { Group Ltd (\%) }\end{array}$ \\
\hline Dividend yield (\%) & 34.72 & 100.00 & 47.05 & 40.06 & 43.21 & 52.66 \\
\hline Earnings yield (\%) & 56.28 & 100.00 & 64.65 & 82.85 & 62.05 & 64.53 \\
\hline Book-to-market ratio & 54.49 & 100.00 & 70.52 & 46.34 & 45.06 & 57.48 \\
\hline Cash-flow-to-price ratio & 56.32 & 98.53 & 64.66 & 61.21 & 58.31 & 58.12 \\
\hline Price-to-earnings ratio & 92.07 & 92.09 & 86.43 & 65.36 & 80.39 & 78.00 \\
\hline Price-to-NAV ratio & 24.66 & 81.03 & 79.89 & 82.91 & 31.18 & 66.45 \\
\hline Return-on-equity (\%) & 60.51 & 89.09 & 63.75 & 83.44 & 84.31 & 67.98 \\
\hline Market cap & 7.30 & 98.39 & 23.48 & 60.68 & 18.34 & 4.38 \\
\hline Implied dividend growth rate & 59.80 & 86.00 & 59.13 & 65.10 & 59.81 & 48.57 \\
\hline Pure technical efficiency (VRS) & 90.84 & 99.12 & 92.22 & 93.08 & 99.09 & 89.26 \\
\hline Scale efficiency & 89.22 & 100.00 & 90.80 & 90.40 & 90.05 & 89.14 \\
\hline Total technical efficiency (CRS) & 87.07 & 100.00 & 90.08 & 91.41 & 97.00 & 85.37 \\
\hline Equally weighted DuPont & 13.98 & 80.00 & 68.05 & 44.57 & 11.37 & 26.69 \\
\hline Sharpe ratio & 38.42 & 80.00 & 50.13 & 48.92 & 44.65 & 24.44 \\
\hline Treynor ratio & 40.37 & 80.00 & 51.58 & 55.47 & 32.65 & 26.66 \\
\hline Jensen's alpha & 36.67 & 80.00 & 49.89 & 56.34 & 31.79 & 25.82 \\
\hline Sortino ratio & 34.11 & 70.66 & 38.11 & 41.76 & 28.02 & 26.78 \\
\hline Calmar ratio & 39.73 & 80.23 & 43.68 & 51.63 & 39.59 & 34.66 \\
\hline VaR-Sharpe ratio & 21.30 & 83.57 & 48.52 & 38.92 & 49.79 & 20.00 \\
\hline Conditional (CVaR) Sharpe ratio & 21.30 & 83.71 & 48.41 & 38.44 & 47.54 & 15.73 \\
\hline Modified (MVaR) Sharpe ratio & 21.84 & 84.14 & 48.49 & 47.86 & 47.65 & 16.31 \\
\hline Static Omega ratio & 66.74 & 82.31 & 64.65 & 67.13 & 63.69 & 58.42 \\
\hline Overall average & 47.63 & 88.58 & 61.10 & 61.54 & 52.98 & 47.16 \\
\hline Overall minimum & 7.30 & 70.66 & 23.48 & 38.44 & 11.37 & 4.38 \\
\hline Overall maximum & 92.07 & 100.00 & 92.22 & 93.08 & 99.09 & 89.26 \\
\hline Average of traditional financial ratios & 46.01 & 92.51 & 62.76 & 63.25 & 49.40 & 52.49 \\
\hline Average of non-financial measures & 89.04 & 99.71 & 91.03 & 91.63 & 95.38 & 87.92 \\
\hline Average of risk-adjusted performance ratios & 35.61 & 80.51 & 49.27 & 49.61 & 42.82 & 27.65 \\
\hline
\end{tabular}

VaR, value at risk; CVaR, conditional value at risk; MVaR, Modified value at risk.

TABLE 7: Average explanatory ability of ratios to explain five years ahead share returns per bank.

\begin{tabular}{|c|c|c|c|c|c|c|}
\hline Ratios under evaluation & $\begin{array}{l}\text { Barclays Africa } \\
\text { Group Ltd }\end{array}$ & $\begin{array}{l}\text { Capitec Bank } \\
\text { Holdings Ltd }\end{array}$ & Firstrand Ltd & Investec Ltd & Nedbank Group Ltd & $\begin{array}{l}\text { Standard Bank } \\
\text { Group Ltd }\end{array}$ \\
\hline Dividend yield (\%) & 33.73 & 100.00 & 35.88 & 36.22 & 36.51 & 48.66 \\
\hline Earnings yield (\%) & 48.50 & 100.00 & 51.29 & 73.66 & 52.56 & 55.63 \\
\hline Book-to-market ratio & 48.30 & 100.00 & 51.69 & 49.31 & 37.16 & 50.21 \\
\hline Cash-flow-to-price ratio & 47.61 & 100.00 & 52.67 & 60.30 & 48.75 & 54.34 \\
\hline Price-to-earnings ratio & 91.31 & 100.00 & 83.40 & 63.54 & 76.31 & 74.26 \\
\hline Price-to-NAV ratio & 23.59 & 100.00 & 98.07 & 78.25 & 30.20 & 65.24 \\
\hline Return-on-equity (\%) & 63.10 & 100.00 & 60.55 & 80.20 & 93.08 & 71.65 \\
\hline Market cap & 5.48 & 100.00 & 4.60 & 46.47 & 7.88 & 3.25 \\
\hline Implied dividend growth rate & 51.24 & 100.00 & 61.83 & 71.14 & 65.56 & 51.02 \\
\hline Pure technical efficiency (VRS) & 86.80 & 100.00 & 91.16 & 91.96 & 99.78 & 85.82 \\
\hline Scale efficiency & 87.06 & 100.00 & 86.78 & 88.19 & 86.83 & 86.95 \\
\hline Total technical efficiency (CRS) & 83.96 & 100.00 & 86.60 & 89.87 & 96.44 & 83.01 \\
\hline Equally weighted DuPont & 7.51 & 100.00 & 52.42 & 50.00 & 9.29 & 18.89 \\
\hline Sharpe ratio & 38.49 & 100.00 & 59.88 & 59.15 & 52.64 & 30.35 \\
\hline Treynor ratio & 40.88 & 100.00 & 61.86 & 68.58 & 37.92 & 32.46 \\
\hline Jensen's alpha & 35.94 & 100.00 & 61.01 & 65.30 & 36.36 & 30.98 \\
\hline Sortino ratio & 31.70 & 87.50 & 46.21 & 39.65 & 24.27 & 31.10 \\
\hline Calmar ratio & 39.86 & 100.00 & 50.92 & 64.28 & 45.74 & 43.62 \\
\hline VaR-Sharpe ratio & 15.21 & 100.00 & 51.67 & 22.56 & 59.90 & 9.36 \\
\hline Conditional (CVaR) Sharpe ratio & 19.56 & 100.00 & 51.43 & 22.25 & 60.71 & 10.17 \\
\hline Modified (MVaR) Sharpe ratio & 21.26 & 100.00 & 51.26 & 34.20 & 61.64 & 11.28 \\
\hline Static Omega ratio & 64.68 & 100.00 & 73.51 & 76.68 & 76.92 & 62.80 \\
\hline Overall average & 44.81 & 99.43 & 60.21 & 60.53 & 54.38 & 45.96 \\
\hline Overall minimum & 5.48 & 87.50 & 4.60 & 22.25 & 7.88 & 3.25 \\
\hline Overall maximum & 91.31 & 100.00 & 98.07 & 91.96 & 99.78 & 86.95 \\
\hline Average of traditional financial ratios & 42.04 & 100.00 & 55.24 & 60.91 & 45.73 & 49.32 \\
\hline Average of non-financial measures & 85.94 & 100.00 & 88.18 & 90.00 & 94.35 & 85.26 \\
\hline Average of risk-adjusted performance ratios & 34.18 & 98.61 & 56.42 & 50.29 & 50.68 & 29.12 \\
\hline
\end{tabular}

VaR, value at risk; CVaR, conditional value at risk; MVaR, Modified value at risk. 
that the ex-post future returns of Capitec Bank Holdings Ltd (90\% on average), Investec Ltd (64\% on average) and Firstrand Ltd ( $60 \%$ on average) are best explained by all the measures over all three investment horizons under evaluation. On the other hand, the ex-post future share returns of Standard Bank Group Ltd is the poorest explained by all the measures (56\% on average), where the risk-adjusted performance measures explained the least (34\% on average). The ability to explain Barclays Africa Group Ltd's ex-post future share returns also ranked second last (58\% on average), with risk-adjusted performance ratios being able to explain only 36\% (on average) over all investment horizons under evaluation.

To conclude the empirical study, until this point pure technical efficiency (VRS), the price-to-earnings ratio and the static Omega ratio were identified as the top performing ratios. However, these measures were only credited with being able to explain ex-post future share returns, but not identified as selecting tools in establishing the ranking order of the top performing banking shares. For this reason, it is also useful from a risk-adjusted perspective, to evaluate the ability of these measures to select the top two, three and four banking shares over the three investment horizons under evaluation. This implies that the ranking orders of the different efficiency scores were compared to the ranking orders derived from evaluating the realised risk-adjusted returns (average returns divided by the annualised standard deviation) over the three investment horizons. Over the one-year investment horizon, Figure 2 reports that pure technical efficiency (VRS) exhibited the greatest success rate, with an average ability to predict $63 \%$ of the top two banking shares (on an ex-post basis), followed by the $\mathrm{P} / \mathrm{E}$ ratio (56\% on average) and the static Omega ratio (50\% on average). However, pure technical efficiency (VRS) and P/E ratio exhibited similar performance in being able to predict the top three and top four banking shares ( $71 \%$ and $72 \%$ on average). It is also noteworthy to report that pure technical efficiency (VRS) and the $\mathrm{P} / \mathrm{E}$ ratio were able to predict $100 \%$ of the top two banking shares during 2008, and to predict $83 \%$ (VRS) and $67 \%$ (P/E ratio) of the top two banking shares over the global financial crisis (estimated from 2008 to 2010). Besides the poor ability of the Omega ratio to predict $66 \%$ (on average, from 2004 to 2011) of the top four banking shares, it exhibited similar performance to pure technical efficiency (VRS) and the $\mathrm{P} / \mathrm{E}$ ratio in predicting the top three banking shares. Furthermore, the static Omega ratio outperformed in predicting $100 \%$ of the top four banking shares in 2008, and exhibited the greatest ability to predict the top four banking shares (83\% on average) over the global financial crisis (estimated from 2008 to 2010). On the other hand, in

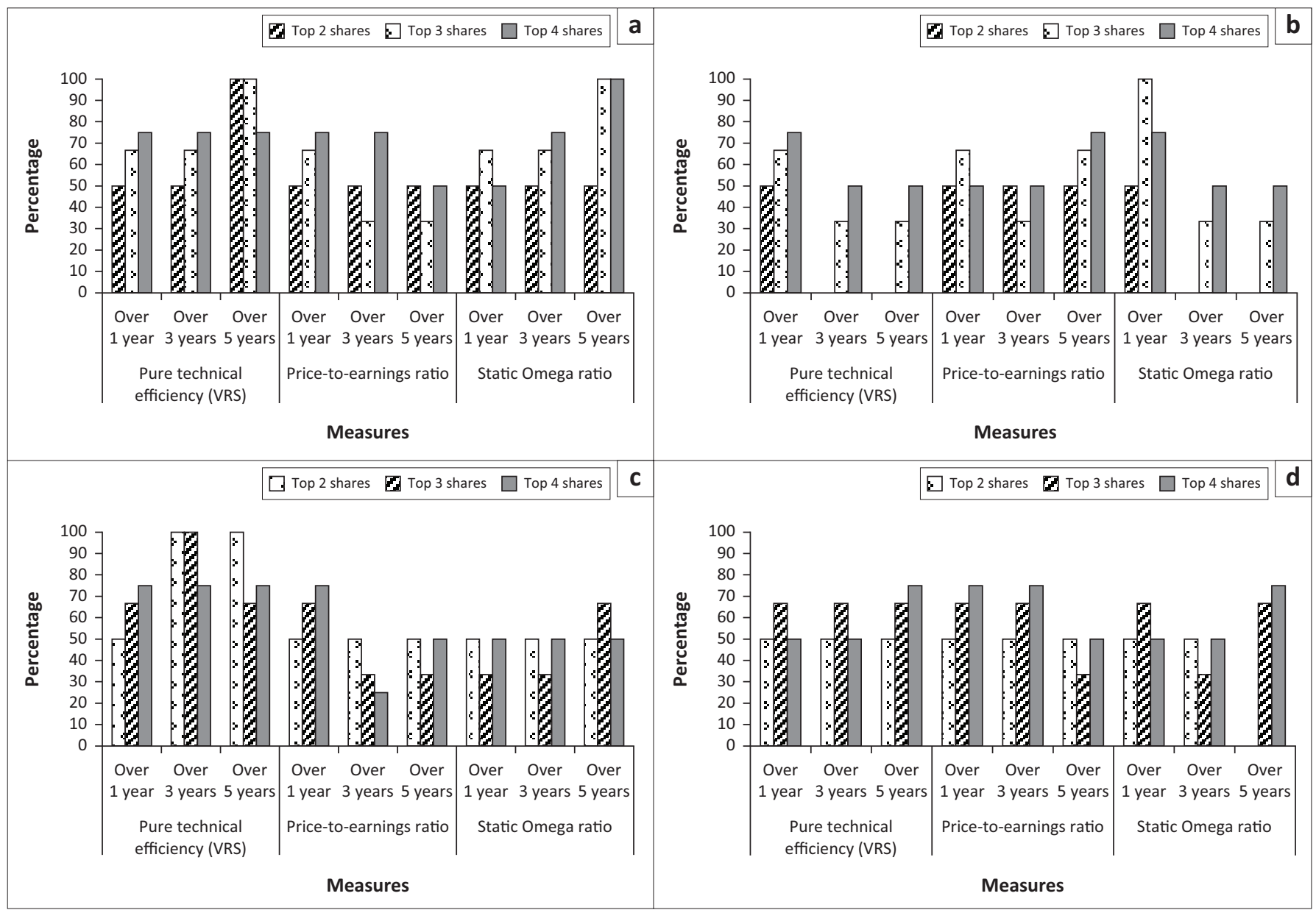

Note: See Table 2-A1 in Appendix 1 for a more detailed report.

FIGURE 2: Average ability of pure technical efficiency (VRS), the P/E ratio and static Omega ratio to select the top performing banking shares: (a) 2004; (b) 2005; (c) 2006; (d) 2007; (e) 2008; (f) 2009; (g) 2010 and (h) 2011. 


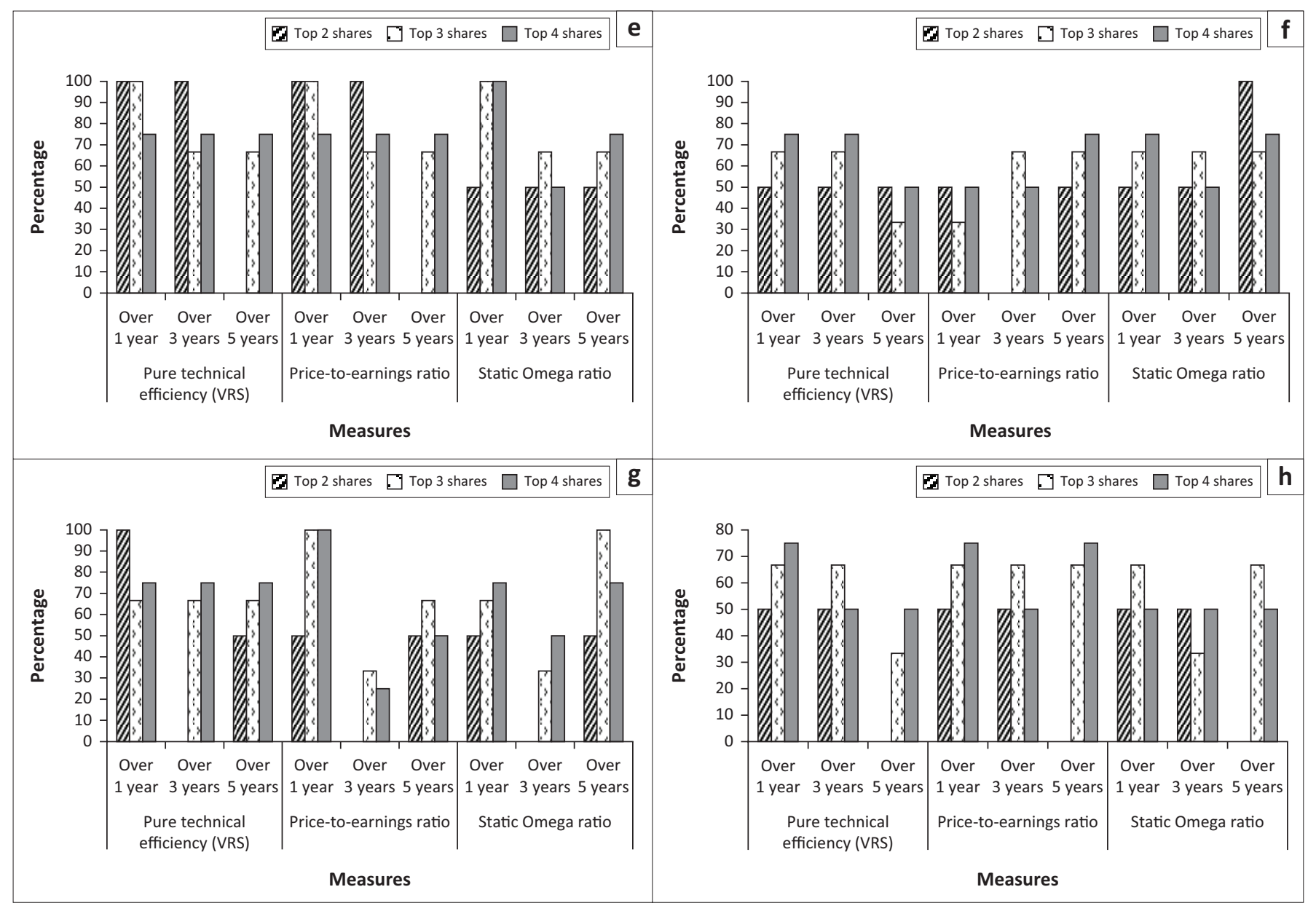

Note: See Table 2-A1 in Appendix 1 for a more detailed report.

FIGURE 2 (Continues...): Average ability of pure technical efficiency (VRS), the P/E ratio and static Omega ratio to select the top performing banking shares: (a) 2004; (b) 2005; (c) 2006; (d) 2007; (e) 2008; (f) 2009; (g) 2010 and (h) 2011.

predicting the top three banking shares over the global financial crisis, all three measures exhibited similar performance ( $78 \%$ on average), and specifically in 2008 where $100 \%$ of the top three banking shares could be predicted by all three measures.

Over a three-year investment horizon, Figure 2 illustrates that pure technical efficiency (VRS) and the $\mathrm{P} / \mathrm{E}$ ratio exhibited the greatest ability in predicting the top two and top four banking shares in 2008 (100\% and 75\%), whereas all three measures exhibited similar performance in being able to predict $67 \%$ of the top three banking shares in 2008 . However, on average, pure technical efficiency (VRS) outperformed the $\mathrm{P} / \mathrm{E}$ and static Omega ratio in predicting the top two, three and top four banking shares over the global financial crisis and over the entire horizon under evaluation (2004 to 2011). However, over the five year investing horizon the static Omega ratio was more dominant in predicting the top three and top four banking shares $(71 \%$ and $69 \%$ on average). The only exception was in predicting the top two banking shares, where pure technical efficiency (VRS) was more dominant $(44 \%$ on average). Nonetheless, the static Omega ratio was better at predicting the top two banking shares in 2008 and more dominant at predicting the top two, three and top four banking shares over the global financial crisis ( $67 \%, 78 \%$ and $75 \%$ on average, respectively). There is only one exception to the former, where all three measures exhibited similar performance in predicting the top three and top four banking shares in 2008 (67\% and 75\% on average). Overall, from these results it is more conclusive that nonfinancial measures may have the tendency to better explain future returns and to select top performing banking shares. Although the results from this study may suggest that pure technical efficiency (VRS), the price-to-earnings ratio and the static Omega ratio are the more 'ideal' set of ratios to consult, it is evident from Figure 2 that there may be a tendency for risk-adjusted measures to be a better share selecting tools over a longer investment horizon.

\section{Conclusion and recommendations}

From the literature it is clear that there is no consensus on the choice of an 'all-inclusive' group of ratios that can be used as a basis to explain future returns. This leaves a gap in the literature to identify the true drivers that will ensure the creation of future portfolio wealth. This study fills this gap by comparing the abilities of financial, non-financial, and risk-adjusted performance ratios to explain ex-post future returns for banks in the South African context for a specifically momentum-based investment strategy over one-, three- and five-year investment horizons. The results find that non-financial measures exhibited 
the overall highest average ability (92\%) to explain ex-post future banking share returns over the three investment horizons, followed by the financial ratios (61\% on average) and riskadjusted performance ratios (51\% on average). The most accurate non-financial measure was pure technical efficiency (VRS), because of its ability to incorporate the interdimensional relationships of banking operations and, in so doing, be less vulnerable to data manipulation. The financial and riskadjusted performance ratios that exhibited the best performance included the P/E and the static Omega. However, with the evaluation of the five top-performing measures per investment horizon, evidence suggested that passive and active portfolio managers may consider different financial ratio compositions, as each investment horizon emphasised a different composition of more 'ideal' performing ratios. Nevertheless, the dominance of non-financial measures was further accentuated by demonstrating pure technical efficiency's (VRS) ability to predict the top performing banking shares over the oneand three-year investment horizons from a risk-adjusted perspective. The static Omega ratio, on the other hand, exhibited greater performance over the five-year investment horizon, in predicting the top three and top four banking shares. This implies that risk-adjusted performance ratios and non-financial measures can be used as a short-, and long-term investment decision-making tool, although the static Omega ratio tended to be a better share-selecting tool over a longer investment horizon.

This study raises a few opportunities for future research. Firstly, additional non-financial measures such as balanced scorecards and the stochastic frontier analysis can also be investigated to determine their ability to explain future share returns as compared to the efficiency ratios used in this study. Secondly, future studies can use the approach used in this study and apply it in other industries or sectors. These studies can also use a wider range of financial and riskadjusted performance ratios. Finally, the ability to explain future returns to some extent may imply that the South African banking industry may be time-varying information efficient. Future studies can therefore determine whether or not rigorous regulation is a function of better share return predictability.

\section{Acknowledgements \\ Competing interests}

The authors have declared that no competing interests exist.

\section{Author's contributions}

Prof. Chris van Heerden was responsible for the empirical study, whereas Dr Johan Coetzee was responsible for the literature study.

\section{Ethical consideration}

This article followed all ethical standards for carrying out research without direct contact with human or animal subjects.

\section{Funding}

This research received no specific grant from any funding agency in the public, commercial, or not-for-profit sectors.

\section{Data availability statement}

Data sharing is not applicable to this article.

\section{Disclaimer}

The views and opinions expressed in this article are those of the authors and do not necessarily reflect the official policy or position of any affiliated agency of the authors.

\section{References}

Abad, C., Thore, S.A. \& Laffarga, J., 2004, 'Fundamental analysis of stocks by two-stage DEA', Managerial and Decision Economics 25(5), 231-241. https://doi.org/ 10.1002/mde.1145

Afonso, A. \& Fernandes, S., 2008, 'Assessing and explaining the relative efficiency of local government', The Journal of Socio-Economics 37(5), 1946-1979.

Aigner, D., Lovell, C.K. \& Schmidt, P., 1977, 'Formulation and estimation of stochastic frontier production function models', Journal of Econometrics 6(1), 21-37. https:// doi.org/10.1016/0304-4076(77)90052-5

Alexakis, P. \& Tsolas, I.E., 2011, 'Appraisal of mutual equity fund performance using data envelopment analysis', Multinational Finance Journal 15(3-4), 273-296.

Allen, R.G.D., 1939, Mathematical analysis for economists, New York, MacMillan.

Ames, D., Brazel, J.F., Jones, K.L., Rich, J.S. \& Zimbelman, M.F., 2012, 'Using nonfinancial measures to improve fraud risk assessments', Current Issues in Auditing 6(1), C28C34. https://doi.org/10.2308/ciia-50168

Amiri, M., Zandieh, M., Vahdani, B., Soltani, R. \& Roshanaei, V., 2010, 'An integrated eigenvector-DEA-TOPSIS methodology for portfolio risk evaluation in the FOREX spot market', Expert Systems with Applications 37(1), 509-516. https://doi. org/10.1016/j.eswa.2009.05.041

Anderson, R.I., Fok, R., Springer, T. \& Webb, J., 2002, 'Technical efficiency and economies of scale: A non-parametric analysis of REIT operating efficiency', European Journal of Operational Research 139(3), 598-612.

Aparicio, J., Cordero, J.M., Gonzalez, M. \& Lopez-Espin, J.J., 2018, 'Using non-radial DEA to assess school efficiency in a cross-country perspective: An empirical analysis of OECD countries', Omega 79, 9-20. https://doi.org/10.1016/j. omega.2017.07.004

Arshinova, T., 2011, 'The banking efficiency measurement using the frontier analysis techniques', Journal of Applied Mathematics 4(3), 165-176.

Artzner, P., Delbaen, F., Eber, J.-M. \& Heath, D., 1997, 'Thinking coherently', Risk 10, 68-71.

Artzner, P., Delbaen, F., Eber, J.M. \& Heath, D., 1999, 'Coherent measures of risk', Mathematical Finance 9(3), 203-228. https://doi.org/10.1111/1467-9965.00068

Asness, C., Porter, R. \& Stevens, R., 2000, 'Predicting stock returns using industryrelative firm characteristics', viewed 03 'November 2017, from https://faculty.som. yale.edu/zhiwuchen/Investments/Predict.pdf.

Auret, C. \& Cline, R., 2011, 'Do the value, size and January effects exist on the JSE?', Investment Analysts Journal 40(74), 29-37. https://doi.org/0.1080/10293523.201 1.11082539

Auret, C.J. \& Sinclaire, R.A., 2006, 'Book-to-market ratio and returns on the JSE', Investment Analysts Journal 35(63), 31-38. https://doi.org/10.1080/10293523.20 06.11082476

Avkiran, N.K., 1997, 'Models of retail performance for bank branches: Predicting the level of key business drivers', International Journal of Bank Marketing 15(6-7) 224-237. https://doi.org/10.1108/02652329710184451

Avkiran, N.K., 1999, 'An application reference for data envelopment analysis in branch banking: Helping the novice researcher', International Journal of Marketing 17(5), 206-220. https://doi.org/10.1108/02652329910292675

Avkiran, N.K. \& Morita, H., 2010, 'Predicting Japanese bank stock performance with a composite relative efficiency metric: A new investment tool', Pacific-Basin Finance Journal 18(3), 254-271.

Azadeh, A., Ghaderi, S.F. \& Maghsoudi, A., 2008, 'Location optimization of solar plants by an integrated hierarchical DEA PCA approach', Energy Policy 36(10) 3993-4004.

Banker, R., Chen, J.Y.S. \& Klumpes, P., 2016, 'A trade-level DEA model to evaluate relative performance of investment fund managers', European Journal of Operational Research 225(3), 903-910. https://doi.org/10.1016/j.ejor.2016. 05.056

Banker, R.D., Charnes, A.W. \& Cooper, W.W., 1984, 'Some models for estimating technical and scale efficiency in data envelopment analysis', Management Sciences 30(9), 1078-1092. https://doi.org/10.1287/mnsc.30.9.1078 
Banz, R.W., 1981, 'The relationship between return and market value of common stocks', Journal of Financial Economics 9(1), 3-18. https://doi.org/ stocks' Journal of Financial

Barak, S. \& Dahooei, J.H., 2018, 'A novel hybrid fuzzy DEA-Fuzzy MADM method for airlines safety evaluation'. Journal of Air Transport Management 73, 134-149. https://doi.org/10.1016/j.jairtraman.2018.09.001

Barclays Africa Ltd, 2016, Barclays Africa Group Limited integrated report, Barclays Africa Ltd, Johannesburg.

Barros, C.P. \& Dieke, P.U., 2008, 'Technical efficiency of African hotels', International Journal of Hospitality Management 27(3), 438-447. https://doi.org/10.1016/j. ijhm.2007.11.004

Barros, C.P., Nektarios, M. \& Assaf, A., 2010, 'Efficiency in the Greek insurance industry', European Journal of Operational Research 205(2), 431-436.

Basiewicz, P.G. \& Auret, C.J., 2010, 'Feasibility of the Fama and French three factor model in explaining returns on the JSE', Investment Analysts Journal 39(71), $13-25$.

Basso, A., Funari, S., 2016, 'DEA performance assessment of mutual funds', Data Envelopment Analysis 2016, 229-287. https://doi.org/10.1007/978-1-48997684-0_8

Basu, S., 1983, 'The relationship between earnings' yield, market value and return for NYSE common stocks: Further evidence', Journal of Financial Economics 12(1), 129-156. https://doi.org/10.1016/0304-405X(83)90031-4

Beccalli, E., Casu, B. \& Girardone, C., 2006, 'Efficiency and stock performance in European banking', Journal of Business Finance \& Accounting 33(1-2), 245-262. https://doi.org/10.1111/j.1468-5957.2006.01362.x

Berzkalne, I. \& Zelgalve, E., 2014, 'Return on equity and company characteristics: An empirical study of industries in Latvia', The 8th International Days of Statistics and Economics, Prague, September, pp. 94-103, viewed 03 November 2017, from https://msed.vse.cz/msed_2014/article/253-Berzkalne-Irina-paper.pdf.

Bessent, A., Bessent, W., Kennington, J. \& Reagan, B., 1982, 'An application of mathematical programming to assess productivity in the Houston independent school district', Management Science 28(12), 1355-1367.

Bhandari, L.C., 1988, 'Debt/equity ratio and expected common stock returns: Empirical evidence', Journal of Finance 43(2), 507-528. https://doi.org/10.2307/ 2328473

Black, F., 1972, 'Capital market equilibrium with restricted borrowing', Journal of Business 45(3), 444-455.

Bonorchis, R., 2017a, 'Capitec's stock price has jumped $50000 \%$ since 2002', Moneyweb, viewed 10 October 2017, from https://www.moneyweb.co.za/news/ companies-and-deals/capitecs-stock-price-has-jumped-50-000-since-2002/.

Bonorchis, R., 2017b, 'Capitec overtakes Nedbank, now SA's fourth-largest bank by value', Fin24, viewed 10 October 2017, from https://www.fin24.com/Companies/ Financial-Services/capitec-overtakes-nedbank-now-sas-fourth-largest-bank-byvalue-20170908.

Boscá, J.E., Liern, V., Martínez, A. \& Sala, R., 2009, 'Increasing offensive or defensive efficiency? An analysis of Italian and Spanish football', Omega 37(1), 63-78.

Businesstech, 2017, 'Capitec is now the second biggest bank in South Africa', Busines Tech, viewed 10 October 2017, from https://businesstech.co.za/news/ banking/189420/capitec-is-now-the-second-biggest-bank-in-south-africa/.

Capitec Bank Ltd., 2017, Capitec Bank Holdings Ltd integrated annual report, viewed 10 October 2017, from https://commondatastorage.googleapis.com/capitecbankco-za/integrated_annual_report.pdf.

Chan, L.K., Hamao, Y. \& Lakonishok, J., 1991, 'Fundamentals and stock returns in Japan', Journal of Finance 46(5), 1739-1764. https://doi.org/10.1111/j.1540-6261.1991. tb04642.x

Charnes, A.W., Cooper, W.W. \& Rhodes, E., 1978, 'Measuring the efficiency of decision making units', European Journal of Operational Research 2(6), 429-444. https:// doi.org/10.1016/0377-2217(78)90138-8

Chen, H.H., 2008, 'Stock selection using data envelopment analysis', Industrial Management \& Data Systems 108(9), 1255-1268. https://doi.org/10.1108/ 02635570810914928

Chen, K. \& Shimerda, T., 1981, 'An empirical analysis of useful financial ratios', Financial Management 10(1), 51-60.

Cheng, H., Lu, Y.C. \& Chung, J.T., 2010, 'Improved slack-based context-dependent DEA - A study of international tourist hotels in Taiwan'. Expert Systems with Applications 37(9), 6452-6458. https://doi.org/10.1016/j.eswa.2010.02.142

Choi, H.S. \& Min, D., 2017, 'Efficiency of well-diversified portfolios: Evidence from data envelopment analysis', Omega 73(December), 104-113. https://doi.org/0.1016/j. omega.2016.12.008

Clark, P., 1997, 'The balanced scorecard', Accountancy Ireland 29(6), 25-26.

Coelli, T., 1998, 'A multi-stage methodology for the solution of orientated DEA models', Operations Research Letters 23(3), 143-150.

Coelli, T., Rao, D.S.P. \& Battese, G., 1998, An introduction to efficiency and productivity analysis, Boston, MA, Kluwer Academic.

Coetzee, J., 2016, 'Financial intermediation theory', in J. Coetzee (ed.), Bank management in South Africa: A risk-based perspective, pp. 3-28, Cape Town, Juta.

Coetzee, J. \& De Beer, J., 2016, 'Financial regulation in the South African banking industry', in J. Coetzee (ed.), Bank management in South Africa: A risk-based perspective, pp. 63-94, Cape Town, Juta.

Cooper, W.W., Seiford, L.M. \& Tone, K., 2007, Data envelopment analysis: A comprehensive text with models, applications, references and DEA-solver software, 2nd edn., New York, Springer.
Davenport, T.O. \& Sherman, H.D., 1987, 'Measuring branch profitability', The Banker's Magazine 170(5), 37-38.

Debreu, G., 1951, 'The coefficient of resource utilization', Econometrica 19(3), 273-292. https://doi.org/10.2307/1906814

Delen, D., Kuzey, C. \& Uyar, A., 2013, 'Measuring firm performance using financial ratios: A decision tree approach', Expert Systems with Applications 40(10) 3970-3983. https://doi.org/0.1016/j.eswa.2013.01.012

Dia, M., 2009, 'A portfolio selection methodology based on data envelopment analysis', INFOR: Information Systems and Operational Research 47(1), 71-79. https://doi.org/10.3138/infor.47.1.71

Dowd, K., 1999, 'A value at risk approach to risk-return analysis', The Journal of Portfolio Management 25(4), 60-67. https://doi.org/10.3905/jpm.1999.319755

Dowd, K., 2000, 'Adjusting for risk: An improved Sharpe ratio', International Review of Economics and Finance 9(3), 209-222.

Edirisinghe, N.C. \& Zhang, X., 2008, 'Portfolio selection under DEA-based relative financial strength indicators: Case of US industries'. Journal of the Operational Research Society 59(6), 842-856. https://doi.org/10.1057/palgrave.jors.2602442

Eling, M. \& Jia, R., 2018, 'Business failure, efficiency, and volatility: Evidence from the European insurance industry'. International Review of Financial Analysis 59, 58-76. https://doi.org/10.1016/j.irfa.2018.07.007

Elyasiani, E. \& Mehdian, S.M., 1990, 'A non-parametric approach to measurement of efficiency and technological change: The case of large US commercial banks', Journal of Financial Services Research 4(2), 157-168.

Esfahanipour, A. \& Mousavi, S., 2011, 'A genetic programming model to generate riskadjusted technical trading rules in stock markets', Expert Systems with Application 38(7), 8438-8445. https://doi.org/10.1016/j.eswa.2011.01.039

Fama, E.F., 1991, 'Efficient capital markets: II', Journal of Finance 46(5), 1575-1617. https://doi.org/10.1111/j.1540-6261.1991.tb04636.x

Fama, E.F. \& French, K.R., 1992, 'The cross-section of expected stock returns', Journa of Finance 47(2), 427-465. https://doi.org/10.1111/j.1540-6261.1992.tb04398.x

Fama, E.F. \& French, K.R., 2017, 'International tests of a five-factor asset pricing model', Journal of Financial Economics 123(3), 441-463.

Fang, H., Wu, J. \& Zeng, C., 2009, 'Comparative study on efficiency performance of listed coal mining companies in China and the US', Energy Policy 37(12), 5140-5148. https://doi.org/10.1016/j.enpol.2009.07.027

Färe, R., Grosskopf, S. and Lovell, C.A.K., 1985, The measurement of efficiency of production, Boston, MA, Kluwer-Nijhoff.

Farrell, M.J., 1957, 'The measurement of productive efficiency', Journal of the Royal Statistical Society. Series A (General) 120(3), 253-290. https://doi.org/10.2307/ 2343100

Favre, L. \& Galeano, J-A., 2002, 'Mean-modified value-at-risk optimization with hedge funds', The Journal of Alternative Investments 5(2), 21-25. https://doi. org/10.3905/jai.2002.319052

Firstrand Ltd, 2016, Firstrand Group annual integrated report, Firstrand Ltd, Johannesburg.

Førsund, F.R. \& Hjalmarsson, L., 1974, 'On the measurement of productive efficiency', The Swedish Journal of Economics 76(2), 141-154.

Gibson, C., 1987, 'How chartered financial analysts view financial ratios', Financial Analyst Journal 43(3), 74-76.

Giokas, D.I. \& Pentzaropoulos, G.C., 2008, 'Efficiency ranking of the OECD member states in the area of telecommunications: A composite AHP/DEA study', Telecommunications Policy 32(9-10), 672-685.

Golany, B. \& Storbeck, J., 1999, 'A data envelopment analysis of the operational efficiency of bank branches', Interfaces 29(3), 14-26.

Grandes, M. \& Pinaud, N., 2004, 'Which policies can reduce the cost of capital in Southern Africa?' OECD Policy Brief No. 25, viewed 03 November 2017, from http://search.oecd.org/countries/swaziland/33722694.pdf.

Gregoriou, G.N. \& Gueyie, J.P., 2003, 'Risk-adjusted performance of funds of hedge funds using a modified Sharpe ratio', The Journal of Wealth Management 6(3), 77-83. https://doi.org/10.3905/jwm.2003.442378

Grosskopf, S., 1996, 'Statistical inference and nonparametric efficiency: A selective survey', Journal of Productivity Analysis 7(2), 161-176. https://doi.org/10.1007/ BF00157039

Halim, E.R., 2010, 'Marketing productivity and profitability of Indonesian public listed manufacturing firms: An application of data envelopment analysis (DEA)' Benchmarking: An International Journal 17(6), 842-857. https://doi.org/10.1108/ Benchmarking: An Inter
14635771011089755

Hoffman, A.J., 2012, 'Stock return anomalies: Evidence from the Johannesburg stock exchange', Investment Analysts Journal 2012(75), 21-41. https://doi.org/10.1080 /10293523.2012.11082542

Hossain, M.K., Kamil, A.A., Baten, M.A. \& Mustafa, A., 2012, 'Stochastic frontier approach and data envelopment analysis to total factor productivity and efficiency measurement of Bangladeshi rice', viewed 31 October 2017, from http://journals. plos.org/plosone/article/file?id=10.1371/journal.pone.0046081\&type=printable.

Hou, K., Karolyi, G.A. \& Kho, B.C., 2011, 'What factors drive global stock returns?' The Review of Financial Studies 24(8), 2527-2574. https://doi.org/10.1093/rfs/hhr013

Hu, J.L., Hsu, H.H., Hsiao, C. \& Tsao, H.Y., 2018, 'Is mobile jumping more efficient? Evidence from major Asia-Pacific telecommunications firms', Asia Pacific Management Review 11, 1-10. https://doi.org/10.1016/j.apmrv.2018.04.001

$\mathrm{Hu}, \mathrm{X.} \mathrm{\&} \mathrm{Liu,} \mathrm{C.,} \mathrm{2018,} \mathrm{'Measuring} \mathrm{efficiency,} \mathrm{effectiveness} \mathrm{and} \mathrm{overall} \mathrm{performance} \mathrm{in}$ the Chinese construction industry', Engineering, Construction and Architectural Management 25(6), 780-797. https://doi.org/10.1108/ECAM-06-2016-0131 
Huang, C.Y., Chiou, C.C., Wu, T.H. \& Yang, S.C., 2015, 'An integrated DEA-MODM methodology for portfolio optimization', Operational Research 15(1), 115-136. methodology for portfolio optimization, Oper
https://doi.org/0.1007/s12351-014-0164-7

Iglesias, G., Castellanos, P. \& Seijas, A., 2010, 'Measurement of productive efficiency with frontier methods: A case study for wind farms', Energy Economics 32(5), 1199-1208.

Investec Ltd., 2017, Investec Group integrated annual report: Risk and basel pillar III disclosures, vol. 2.

IRESS INET BFA, 2017, 'Data source', viewed 10 October 2017, from https://www. secure.mcgbfa.com/.

Isik, I. \& Topuz, J.C., 2017, 'Meet the "born efficient" financial institutions: Evidence from the boom years of US REITs', The Quarterly Review of Economics and Finance 66, 70-99. https://doi.org/10.1016/j.qref.2017.07.017

Jacobs, R., 2001, 'Alternative methods to examine hospital efficiency: Data envelopment analysis and stochastic frontier analysis', Health Care Management Science 4(2), 103-115. https://doi.org/10.1023/A:1011453526849

Jaforullah, M. \& Whiteman, J., 1999, 'Scale efficiency in the New Zealand dairy industry: A non-parametric approach', The Australian Journal of Agricultural and Resource Economics 43(4), 523-541. https://doi.org/10.1111/1467-8489.00093

Jegadeesh, N. \& Titman, S., 1993, 'Returns to buying winners and selling losers: Implications for stock market efficiency', Journal of Finance 48(1), 65-91. https:// doi.org/10.2307/2328882

Jensen, M.C., 1968, 'The performance of mutual funds in the period 1945-1964', Journal of Finance 23(2), 389-416.

Johannes, M., Korteweg, A. \& Polson, N., 2014, 'Sequential learning, predictability, and optimal portfolio returns', Journal of Finance 69(2), 611-644. https://doi. org/10.1111/jofi.12121

Johnson, H.T. \& Kaplan, R.S., 1987, Relevance Lost: The rise and fall of management accounting, Boston, MA, Harvard Business School.

Joro, T. \& Na, P., 2006, 'Portfolio performance evaluation in a mean-variance-skewness framework', European Journal of Operational Research 175(1), 446-461. https:// doi.org/10.1016/j.ejor.2005.05.006

Kahraman, C., Uluğ, I.., Othan, C.B., Özkan-Özen, Y.D. \& Kazançoğlu, Y., 2018, 'Efficiency analysis in retail sector: Implementation of data envelopment analysis in a local supermarket chain', in The International Symposium for Production Research, Cham, Springer.

Kaparakis, E.I., Miller, S.M. \& Noulas, A.G., 1994, 'Short-run cost inefficiency of commercial banks: A flexible stochastic frontier approach', Journal of Money, Credit and Banking 26(4), 875-893. https://doi.org/10.2307/2077953

Kaplan, R.S. \& Norton, D.P., 1996, 'Using the balanced scorecard as a strategic management system', Harvard Business Review 74(1), 75-85.

Keating, C. \& Shadwick, W.F., 2002, 'A universal performance measure', Journal of Performance Measurement 6(3), 59-84.

Kirigia, J. M., Sambo, L.G. \& Scheel, H., 2001, 'Technical efficiency of public clinics in Kwazulu-Natal province of South Africa', East-African Medical Journal 78(3), 1-13. https://doi.org/10.4314/eamj.v78i3.9070

Kittelsen, S.A., 1999, Monte Carlo simulations of DEA efficiency measures and hypothesis tests (No. 1999, 09), Memorandum, Department of Economics,
University of Oslo, viewed 31 October 2017, https://www.econstor.eu/ bitstream/10419/63113/1/323421636.pdf.

Koopmans, T. C., 1951, 'An analysis of production as an efficient combination of activities', in T.C. Koopmans (ed.), Activity analysis of production and allocation, John Wiley and Sons, New York.

Kuhn, L., Balezentis, T., Hou, L. \& Wang, D., 2018, 'Technical and environmental efficiency of livestock farms in China: A slacks-based DEA approach', China Economic Review 1-14. https://doi.org/10.1016/j.chieco.2018.08.009

Kumar, N. \& Singh, A., 2014, 'Efficiency analysis of banks using DEA: A review', International Journal of Advance Research and Innovation 1, 120-126.

Kuosmanen, T., 2007, 'Performance measurement and best-practice benchmarking of mutual funds: Combining stochastic dominance criteria with data envelopment analysis', Journal of Productivity Analysis 28(1-2), 71-86. https://doi.org/10.1007/ s11123-007-0045-7

Lakonishok, J., Shleifer, A. \& Vishny, R.W., 1994, 'Contrarian investment, extrapolation, and risk', Journal of Finance 49(5), 1541-1578. https://doi.org/10.1111/j.15406261.1994.tb04772.x

Lim, S., Oh, K.W. \& Zhu, J., 2014, 'Use of DEA cross-efficiency evaluation in portfolio selection: An application to Korean stock market', European Journal of Operational Research 236(1), 361-368. https://doi.org/10.1016/j.ejor.2013.12.002

Lintner, J., 1965, 'The valuation of risk assets and the selection of risky investments in stock portfolios and capital assets', Review of Economics and Statistics 47(1), 13-37. https://doi.org/10.2307/1924119

Litzenberger, R.H. \& Ramaswamy, K., 1979, 'The effect of personal taxes and dividends on capital asset prices: Theory and empirical evidence', Journal of Financial Economics 7(2), 163-195. https://doi.org/10.1016/0304-405X(79)90012-6

Liu, J.S., Lu, L.Y., Lu, W.M. \& Lin, B.J., 2013, 'A survey of DEA applications', Omega 41(5), 893-902. https://doi.org/10.1016/j.omega.2012.11.004

Liu, S.T., 2008, 'A fuzzy DEA/AR approach to the selection of flexible manufacturing systems', Computers \& Industrial Engineering 54(1), 66-76. https://doi. org/0.1016/j.cie.2007.06.035

Liu, W., Zhou, Z., Liu, D. \& Xiao, H., 2015, 'Estimation of portfolio efficiency via DEA', Omega 52(April), 107-118. https://doi.org/10.1016/j.omega.2014.11.006
Lovell, C.A.K. \& Pastor, J.T., 1995, 'Units invariant and translation invariant DEA models', Operations Research Letters 18(3), 147-152. https://doi.org/10.1016/ 0167-6377(95)00044-5

Mahadevan, R., 2002, 'A DEA approach to understanding the productivity growth of Malaysia's manufacturing industries', Asia Pacific Journal of Management 19(4), 587-600. https://doi.org/10.1023/A:1020577811369

Mashayekhi, Z. \& Omrani, H., 2016, 'An integrated multi-objective Markowitz-DEA cross-efficiency model with fuzzy returns for portfolio selection problem', Applied Soft Computing 38(January), 1-9. https://doi.org/10.1016/j.asoc.2015.09.018

Matsumoto, K., Shivaswamy, M. \& Hoban, J., 1995, 'Security analysts' views of the financial ratios of manufacturers and retailers', Financial Practice and Education 5(2), 44-55.

Meeusen, W. \& Van Den Broeck, J., 1977, 'Efficiency estimation from Cobb-Douglas production functions with composed error', International Economic Review 18(2), 435-444. https://doi.org/10.2307/2525757

Mester, L.J., 1993, 'Efficiency of banks in the third Federal Reserve district', Working paper 94-13, viewed 25 October 2017, from http://citeseerx.ist.psu.edu/ viewdoc/download?doi=10.1.1.36.3776\&rep=rep1\&type=pdf.

Mester, L.J., 2003, 'Applying efficiency measurement techniques to central banks', Working paper $03-13$, viewed 25 October 2017, from https://philadelphiafed. org/-/media/research-and-data/publications/working-papers/2003/wp0313.pdf.

Mossin, J., 1966, 'Equilibrium in a capital asset market', Econometrica 34(4), 768-783. https://doi.org/10.2307/1910098

Muller, C. \& Ward, M., 2013, 'Style-based effects on the Johannesburg Stock Exchange: A graphical time-series approach', Investment Analysts Journal 2013(77), 1-16.

Nedbank Ltd, 2016, Basel III public disclosure report: Pillar 3 risk and capital management report, Nedbank Ltd, Johannesburg.

Nunamaker, T.R., 1983, 'Measuring routine nursing service efficiency: A comparison of cost per patient day and data envelopment analysis models', Health Services Research 18, 183-208.

Nunamaker, T.R., 1985, 'Using data envelopment analysis to measure the efficiency of non-profit: A critical evaluation', Managerial and Decision Economics 6(1), 50-58. https://doi.org/10.1002/mde.4090060109

Omrani, H., Shafaat, K. \& Emrouznejad, A., 2018, 'An integrated fuzzy clustering cooperative game data envelopment analysis model with application in hospital efficiency', Expert Systems with Applications 114), 615-628. https://doi. efficiency', Expert Systems with
org/10.1016/j.eswa.2018.07.074

Pätäri, E., Leivo, T. \& Honkapuro, S., 2012, 'Enhancement of equity portfolio performance using data envelopment analysis', European Journal of Operational Research 220(3), 786-797.

Pätäri, E.J., Leivo, T.H. \& Honkapuro, S., 2010, ‘Enhancement of value portfolio performance using data envelopment analysis', Studies in Economics and Finance 27(3), 223-246. https://doi.org/10.1108/10867371011060036

Pech, C.O.T., Noguera, M. \& White, S., 2015, 'Financial ratios used by equity analysts in Mexico and stock returns', Contaduría y Administración 60, 578-592. https:// doi.org/10.1016/j.cya.2015.02.001

Quaranta, A.G., Raffoni, A. \& Visani, F., 2018, 'A multidimensional approach to measuring bank branch efficiency', European Journal of Operational Research 266(2), 746-760. https://doi.org/10.1016/j.ejor.2017.10.009

Resende, M. \& Façanha, L.O., 2005, 'Price-cap regulation and service-quality in telecommunications: An empirical study', Information Economics and Policy 17(1), $1-12$.

Roboredo, M.C., Aizemberg, L. \& Meza, L.A., 2015, 'The DEA game cross efficiency model applied to the Brazilian football championship', Procedia Computer Science 55, 758-763. https://doi.org/10.1016/j.procs.2015.07.161

Rosenberg, B., Reid, K. \& Lanstein, R., 1985, 'Persuasive evidence of market inefficiency', The Journal of Portfolio Management 11(3), 9-16. https://doi. org/10.3905/jpm.1985.409007

Schefczyk, M., 1993, 'Operational performance of airlines - An extension of traditional measurement paradigms', Strategic Management Journal 14, 301-317.

Sealey, C.W. \& Lindley, J.T., 1977, 'Inputs, outputs and a theory of production and cost as depositary financial institutions', Journal of Finance 32(4), 1251-1266.

Sharma, K.R., Leung, P. \& Zaleski, H.M., 1999, 'Technical, allocative and economic efficiencies in swine production in Hawaii: A comparison of parametric and nonparametric approaches', Agricultural Economics 20(1), 23-35. https://doi. org/10.1016/S0169-5150(98)00072-3

Sharpe, W., 1964, 'Capital asset prices: A theory of market equilibrium under conditions of risk', Journal of Finance 19(3), 425-442. https://doi.org/10. $2307 / 2977928$

Sharpe, W.F., 1966, 'Mutual fund performance', Journal of Business 39(1), 119-138.

Shephard, R.W., 1953, Cost and production functions, Princeton, NJ, Princeton University Press.

Shephard, R.W., 1970, Cost and production functions, Princeton, NJ, Princeton University Press.

Sherman, G. \& Gold, F., 1985, 'Bank branch operating efficiency - Evaluation with data envelopment analysis', Journal of Banking \& Finance 9, 297-315. https://doi. org/10.1016/0378-4266(85)90025-1

Shi, G.M., Bi, J. \& Wang, J.N., 2010, 'Chinese regional industrial energy efficiency evaluation based on a DEA model of fixing non-energy inputs', Energy Policy 38(10), 6172-6179. https://doi.org/10.1016/j.enpol.2010.06.003 
Singleton-Green, B., 1993, 'If it matters, measure it', Accountancy 111(1197), 52-53.

Soliman, M.T., 2008, 'The use of Du Pont analysis by market participants', The Accounting Review 83(3), 823-853. https://doi.org/10.2308/accr.2008.83.3.823

Sortino, F.A. \& Van Der Meer, R., 1991, 'Downside risk', Journal of Portfolio Management 17(4), 27-31.

South African Reserve Bank (SARB), 2016, Bank Supervision Department, annual report, viewed 10 October 2017, from https://www.resbank.co.za/fastsearch/ Pages/Results.aspx?sq=1\&k=BankSupervision Report

South African Reserve Bank (SARB), 2017a, 'Data source', viewed 13 October 2017, https://www.resbank.co.za.

South African Reserve Bank (SARB), 2017b, 'Financial stability review', viewed 10 October 2017, from https://www.rba.gov.au/publications/fsr/2016/oct/pdf/ financial-stability-review-2016-10.pdf.

Standard Bank Group Ltd, 2016, Risk and capital management report and annual financial statements, Standard Bank Group Ltd, Johannesburg.

Stattman, D., 1980, 'Book values and stock returns', The Chicago MBA: A Journal of Selected Papers 4(1), 25-45.

Stemmet, K., 2016, 'The competitive and operating environment of the South African Banking Industry', in J. Coetzee (ed.), Bank management in South Africa: A riskbased perspective, pp. 3-62, Cape Town, Juta.

Sueyoshi, T., Goto, M. \& Ueno, T., 2010, 'Performance analysis of US coal-fired powe plants by measuring three DEA efficiencies', Energy Policy 38(4), 1675-1688. https://doi.org/10.1016/j.enpol.2009.11.017

Sufian, F. \& Majid, M.Z.A., 2007, 'Singapore banking efficiency and its relation to stock returns: A DEA window analysis approach', International Journal of Business Studies 15(1), 83-106.

Tarim, S.A. \& Karan, M.B., 2001, 'Investment fund performance measurement using weight-restricted data envelopment analysis: An application to the Turkish capital market', Russian \& East European Finance and Trade 37(5), 64-84.

Titko, J., Stankevičienè, J. \& Lāce, N., 2014, 'Measuring bank efficiency: DEA application'. Technological and Economic Development of Economy 20(4) 739-757.

Topuz, J.C., Darrat, A.F. \& Shelor, R.M., 2005, 'Technical, allocative and scale efficiencies of REITs: An empirical inquiry', Journal of Business Finance \& Accounting 32(9-10), 1961-1994. https://doi.org/10.1111/j.0306-686X.2005.00653.x

Traub, E., 2001, 'Using ROE to analyze stocks: What you need to know about', American Association of Individual Investor Journal, July, 4-7, viewed 13 October 2017, from https://www.aaii.com/journal/article/using-roe-to-analyze-stockswhat-you-need-to-know-about.

Treynor, J.L., 1965, 'How to rate management investment funds', Harvard Business Review 43(1), 63-75. https://doi.org/10.1002/9781119196679.ch10

Tsolas, I.E., 2011, 'Modelling profitability and effectiveness of Greek-listed construction firms: An integrated DEA and ratio analysis', Construction Management and Economics 29(8), 795-807. https://doi.org/10.1080/01446193.2011.610330

Van Heerden, C., 2016, 'The eminence of risk-free rates in portfolio management: A South African perspective', The Journal of Applied Business Research 32(2), 569-596. https://doi.org/10.19030/jabr.v32i2.9597

Van Heerden, C. \& Heymans, A., 2013, 'A fundamental evaluation of the top five South African banks after the financial crisis', Journal of Economic and Financial Sciences 6(3), 731-762.

Van Heerden, C. \& Rossouw, R., 2014, 'Resource utilisation efficiency: A South African provincial evaluation', South African Journal of Economics 82(4), 475-492. https:// doi.org/10.1111/saje.12037

Van Heerden, C. \& Saayman, M., 2018, 'Sustainability of a national arts festival: An application of a data envelopment analysis approach', Tourism Economics 24(5), 576-592. https://doi.org/10.1177/1354816618762186

Van Heerden, C. \& Van Der Westhuizen, G., 2008, 'The cost of banking services and the technical efficiency of a South African bank,' The Journal for Transdisciplinary Research in Southern Africa 4(2), 401-417. https://doi.org/10.4102/td v4i2.160

Van Rensburg, P., 2001, 'A decomposition of style-based risk on the JSE', Investmen Analysts Journal 30(54), 45-60. https://doi.org/10.1080/10293523.2001.11082431
Van Rensburg, P.V. \& Robertson, M., 2003, 'Size, price-to-earnings and beta on the JSE securities exchange', Investment Analysts Journal 32(58), 7-16. https://doi.org/10 .1080/10293523.2003.11082449

Wang, W. \& Zhang, C., 2018, 'Evaluation of relative technological innovation capability: Model and case study for China's coal mine', Resources Policy 58, 144-149. https://doi.org/10.1016/j.resourpol.2018.04.008

Wanke, P. \& Barros, C.P., 2016, 'Efficiency drivers in Brazilian insurance: A two-stage DEA meta frontier-data mining approach', Economic Modelling 53, 8-22. https:// doi.org/10.1016/j.econmod.2015.11.005

Wheelock, D.C. \& Wilson, P.W., 1995, 'Explaining bank failures: Deposit insurance, regulation, and efficiency', Review of Economics and Statistics 77(4), 689-700.

World Economic Forum, 2008, The Global Competitiveness Report, 2008-2009, WEF, Cologny.

World Economic Forum, 2009, The Global Competitiveness Report, 2009-2010, WEF, Cologny.

World Economic Forum, 2010, The Global Competitiveness Report, 2010-2011, WEF, Cologny.

World Economic Forum, 2011, The Global Competitiveness Report, 2011-2012, WEF, Cologny.

World Economic Forum, 2012, The Global Competitiveness Report, 2012-2013, WEF, Cologny.

World Economic Forum, 2013, The Global Competitiveness Report, 2013-2014, WEF, Cologny.

World Economic Forum, 2014, The Global Competitiveness Report, 2014-2015, WEF, Cologny.

World Economic Forum, 2015, The Global Competitiveness Report, 2015-2016, WEF, Cologny.

World Economic Forum, 2016, The Global Competitiveness Report, 2016-2017, WEF, Cologny.

World Economic Forum, 2017, The Global Competitiveness Report, 2017-2018, WEF, Cologny.

Worthington, A.C., 2004, 'Frontier efficiency measurement in health care: A review of empirical techniques and selected applications', Medical Care Research and Review 61(2), 135-170. https://doi.org/10.1177/1077558704263796

Xavier, J.M., Moutinho, V.F. \& Moreira, A.C., 2015, 'An empirical examination of performance in the clothing retailing industry: A case study', Journal of Retailing and Consumer Services 25, 96-105. https://doi.org/10.1016/j.jretconser.2015.04.002

Xia, Q., Jin, M., Wu, H. \& Yang, C., 2018, 'A DEA-based decision framework to determine the subsidy rate of emission reduction for local government', Journal of Cleaner Production 202, 846-852. https://doi.org/10.1016/j.jclepro.2018. 08.171

Xue, X., Shen, Q., Wang, Y. \& Lu, J., 2008, 'Measuring the productivity of the construction industry in China by using DEA-based Malmquist productivity indices', Journal of Construction engineering and Management 134(1), 64-71.

Yang, Z., 2009, 'Bank branch operating efficiency: A DEA approach', Proceedings of the International MultiConference of Engineers and Computer Scientists 2, 18-20.

Young, T.W., 1991, 'Calmar ratio: A smoother tool', Futures 20(1), 40.

Zaremba, A. \& Czapkiewicz, A., 2017, 'Digesting anomalies in emerging European markets: A comparison of factor pricing models', Emerging Markets Review 31(June), 1-15. https://doi.org/10.1016/j.ememar.2016.12.002

Zere, E., Mbeeli, T., Shangula, K., Mandlhate, C., Mutirua, K., Tjivambi, B. et al., 2006, 'Technical efficiency of district hospitals: Evidence from Namibia using data envelopment analysis', Cost Effectiveness and Resource Allocation 4(1), 1-9. https://doi.org/10.1186/1478-7547-4-5

Zhu, J., 2016, 'DEAFrontier', viewed 27 June 2017, from http://www.deafrontier.net/ deasupport/index.html.

Zurano-Cervelló, P., Pozo, C., Mateo-Sanz, J.M., Jiménez, L. \& Guillén-Gosálbez, G., 2018 , 'Electricity mix assessment of the EU member countries using DEA and EffMixF', Computer Aided Chemical Engineering 43, 445-450. 


\section{Appendix 1}

TABLE 1-A1: Average ability to explain future returns (across all banks).

\begin{tabular}{|c|c|c|c|}
\hline Ratios under evaluation & Explain 5 years ahead (\%) & Explain 3 years ahead (\%) & Explain 1 year ahead (\%) \\
\hline Dividend yield (\%) & 48.50 & 52.95 & 56.78 \\
\hline Earnings yield (\%) & 63.61 & 71.73 & 70.78 \\
\hline Book-to-market ratio & 56.11 & 62.31 & 60.56 \\
\hline Cash-flow-to-price ratio & 60.61 & 66.19 & 66.67 \\
\hline Price-to-earnings ratio & 81.47 & 82.39 & 83.23 \\
\hline Price-to-NAV ratio & 65.89 & 61.02 & 60.90 \\
\hline Return-on-equity (\%) & 78.10 & 74.85 & 75.63 \\
\hline Market capitalisation & 27.95 & 35.43 & 37.78 \\
\hline Implied dividend growth rate & 66.80 & 63.07 & 64.85 \\
\hline Pure technical efficiency (VRS) & 92.59 & 93.94 & 94.31 \\
\hline Scale efficiency & 89.30 & 91.60 & 92.21 \\
\hline Total technical efficiency (CRS) & 89.98 & 91.82 & 92.09 \\
\hline Equally weighted DuPont & 39.69 & 40.78 & 42.43 \\
\hline Sharpe ratio & 56.75 & 47.76 & 53.83 \\
\hline Treynor ratio & 56.95 & 47.79 & 56.85 \\
\hline Jensen's alpha & 54.93 & 46.75 & 53.49 \\
\hline Sortino ratio & 43.40 & 39.91 & 48.90 \\
\hline Calmar ratio & 57.40 & 48.25 & 54.63 \\
\hline VaR-Sharpe ratio & 43.12 & 43.68 & 40.87 \\
\hline Conditional (CVaR) Sharpe ratio & 44.02 & 42.52 & 42.60 \\
\hline Modified (MVaR) Sharpe ratio & 46.61 & 44.38 & 44.07 \\
\hline Static Omega ratio & 75.77 & 67.16 & 69.02 \\
\hline Overall average & 60.89 & 59.83 & 61.93 \\
\hline Overall minimum & 27.95 & 35.43 & 37.78 \\
\hline Overall maximum & 92.59 & 93.94 & 94.31 \\
\hline Average of traditional financial ratios & 58.87 & 61.07 & 61.96 \\
\hline Average of non-financial measures & 90.62 & 92.45 & 92.87 \\
\hline Average of risk-adjusted performance ratios & 53.22 & 47.58 & 51.59 \\
\hline
\end{tabular}

VaR, value at risk; CVaR, conditional value at risk; MVaR, Modified value at risk. 
TABLE 2-A1: Average ability of pure technical efficiency (VRS), the P/E ratio and static Omega ratio to select the top performing banking shares.

\begin{tabular}{|c|c|c|c|c|c|c|c|c|c|c|}
\hline \multirow[t]{2}{*}{ Year } & \multirow[t]{2}{*}{ Shares } & \multicolumn{3}{|c|}{ Pure technical efficiency (years) } & \multicolumn{3}{|c|}{ Price-to-earnings ratio } & \multicolumn{3}{|c|}{ Static omega ratio } \\
\hline & & $\begin{array}{c}\text { Over } \\
1 \text { year (\%) }\end{array}$ & $\begin{array}{c}\text { Over } \\
3 \text { years (\%) }\end{array}$ & $\begin{array}{c}\text { Over } \\
5 \text { years (\%) }\end{array}$ & $\begin{array}{c}\text { Over } \\
1 \text { year }(\%)\end{array}$ & $\begin{array}{c}\text { Over } \\
3 \text { years (\%) }\end{array}$ & $\begin{array}{c}\text { Over } \\
5 \text { years (\%) }\end{array}$ & $\begin{array}{c}\text { Over } \\
1 \text { year }(\%)\end{array}$ & $\begin{array}{c}\text { Over } \\
3 \text { years (\%) }\end{array}$ & $\begin{array}{c}\text { Over } \\
5 \text { years }(\%)\end{array}$ \\
\hline 2004 & Top 2 shares & 50.00 & 50.00 & 100.00 & 50.00 & 50.00 & 50.00 & 50.00 & 50.00 & 50.00 \\
\hline 2005 & Top 2 shares & 50.00 & 0.00 & 0.00 & 50.00 & 50.00 & 50.00 & 50.00 & 0.00 & 0.00 \\
\hline 2006 & Top 2 shares & 50.00 & 100.00 & 100.00 & 50.00 & 50.00 & 50.00 & 50.00 & 50.00 & 50.00 \\
\hline 2007 & Top 2 shares & 50.00 & 50.00 & 50.00 & 50.00 & 50.00 & 50.00 & 50.00 & 50.00 & 0.00 \\
\hline 2008 & Top 2 shares & 100.00 & 100.00 & 0.00 & 100.00 & 100.00 & 0.00 & 50.00 & 50.00 & 50.00 \\
\hline 2009 & Top 2 shares & 50.00 & 50.00 & 50.00 & 50.00 & 0.00 & 50.00 & 50.00 & 50.00 & 100.00 \\
\hline 2010 & Top 2 shares & 100.00 & 0.00 & 50.00 & 50.00 & 0.00 & 50.00 & 50.00 & 0.00 & 50.00 \\
\hline 2011 & Top 2 shares & 50.00 & 50.00 & 0.00 & 50.00 & 50.00 & 0.00 & 50.00 & 50.00 & 0.00 \\
\hline 2004 & Top 3 shares & 66.67 & 66.67 & 100.00 & 66.67 & 33.33 & 33.33 & 66.67 & 66.67 & 100.00 \\
\hline 2005 & Top 3 shares & 66.67 & 33.33 & 33.33 & 66.67 & 33.33 & 66.67 & 100.00 & 33.33 & 33.33 \\
\hline 2006 & Top 3 shares & 66.67 & 100.00 & 66.67 & 66.67 & 33.33 & 33.33 & 33.33 & 33.33 & 66.67 \\
\hline 2007 & Top 3 shares & 66.67 & 66.67 & 66.67 & 66.67 & 66.67 & 33.33 & 66.67 & 33.33 & 66.67 \\
\hline 2008 & Top 3 shares & 100.00 & 66.67 & 66.67 & 100.00 & 66.67 & 66.67 & 100.00 & 66.67 & 66.67 \\
\hline 2009 & Top 3 shares & 66.67 & 66.67 & 33.33 & 33.33 & 66.67 & 66.67 & 66.67 & 66.67 & 66.67 \\
\hline 2010 & Top 3 shares & 66.67 & 66.67 & 66.67 & 100.00 & 33.33 & 66.67 & 66.67 & 33.33 & 100.00 \\
\hline 2011 & Top 3 shares & 66.67 & 66.67 & 33.33 & 66.67 & 66.67 & 66.67 & 66.67 & 33.33 & 66.67 \\
\hline 2004 & Top 4 shares & 75.00 & 75.00 & 75.00 & 75.00 & 75.00 & 50.00 & 50.00 & 75.00 & 100.00 \\
\hline 2005 & Top 4 shares & 75.00 & 50.00 & 50.00 & 50.00 & 50.00 & 75.00 & 75.00 & 50.00 & 50.00 \\
\hline 2006 & Top 4 shares & 75.00 & 75.00 & 75.00 & 75.00 & 25.00 & 50.00 & 50.00 & 50.00 & 50.00 \\
\hline 2007 & Top 4 shares & 50.00 & 50.00 & 75.00 & 75.00 & 75.00 & 50.00 & 50.00 & 50.00 & 75.00 \\
\hline 2008 & Top 4 shares & 75.00 & 75.00 & 75.00 & 75.00 & 75.00 & 75.00 & 100.00 & 50.00 & 75.00 \\
\hline 2009 & Top 4 shares & 75.00 & 75.00 & 50.00 & 50.00 & 50.00 & 75.00 & 75.00 & 50.00 & 75.00 \\
\hline 2010 & Top 4 shares & 75.00 & 75.00 & 75.00 & 100.00 & 25.00 & 50.00 & 75.00 & 50.00 & 75.00 \\
\hline 2011 & Top 4 shares & 75.00 & 50.00 & 50.00 & 75.00 & 50.00 & 75.00 & 50.00 & 50.00 & 50.00 \\
\hline
\end{tabular}

VRS, variable returns to scale. 